IBAD Sosyal Bilimler Dergisi

IBAD Journal of Social Sciences

dergipark.org.tr/ibad

IBAD, 2021; (9): 28-62

DOI: $10.21733 / \mathrm{ibad} .835750$

Özgün Araştırma / Original Article

Türkiye Türkçesinde 1930’lu Yıllardan Sonra Türetilen veya Canlandırılan Yeni
Sözcüklerin Ağız Metinlerine Etkisinin Bir Örneklem Üzerinden Değerlendirilmesi

Evaluation of the Effects of the New Words Derived or Revived Turkish after the 1930s on the

Dialectical Texts over a Sample

\title{
Anıl Çelik
}

* Sorumlu yazar

Corresponding author

${ }^{1}$ Dr. Öğr. Üyesi, Bartın Üniversitesi, Türkiye Assist. Prof. Dr., Bartın University, Turkey acelik@bartin.edu.tr ORCID ID 0000-0001-6035-5303

Makale geliş tarihi / First received : 04.12.2020

Makale kabul tarihi / Accepted : :23.12.2020

Bilgilendirme / Acknowledgement:

Yazar aşağıdaki bilgillendirmeleri yapmaktadır:

1- Makalemizde etik kurulu izni ve/veya yasal/özel izin alınmasını gerektiren bir durum yoktur. Makalemizde 2020 yılı öncesinde yürütülmüş çalışmalara ait bazı araştırma verileri kaynak gösterilerek kullanılmıştır.

2- Bu makalede araştırma ve yayın etiğine uyulmuştur.

This article was checked by iThenticate. Similarity Index 05\%

Atıf bilgisi / Citation:

Çelik, A. (2021). Türkiye Türkçesinde 1930'lu yıllardan sonra türetilen veya canlandırılan yeni sözcüklerin ağız metinlerine etkisinin bir örneklem üzerinden değerlendirilmesi. IBAD Sosyal Bilimler Dergisi, (9), 28-62. 


\section{Öz}

Kitle iletişim araçlarının yaygınlaşmasının Türkiye Türkçesi ağızlarını yoğun bir biçimde etkilediği birçok kaynakta ifade edilmektedir. Bununla birlikte, ağız derlemelerinin kaynak kişilerinde bulunması gereken özellikler sıralanırken; öğrenim durumu, yöreden ayrılmamış olma, yaş, yörenin ağız özelliklerini taşıma, cinsiyet, meslek, büyük yerleşim merkezleriyle iletişim durumu gibi nitelikler ön plana çıkarılır. Zira ilgili kaynaklara göre bu nitelikler, ağızların yaşadığı etkileşimleri önemli ölçüde yansitır. Söz konusu düşünceleri bilimsel bir yöntemle sınamak adına Türkiye Türkçesinde 1930'lu yıllardan sonra türetilen veya canlandırılan yeni sözcüklerin ağız metinlerine etkisinin ölçülmeye çalışılması birtakım yönlendirici veriler sağlayabilir. Çünkü yeni türetilen sözcüklerin halk diline geçmesi konusunda yazı dili, kitle iletişim araçları ve teknoloji son derece etkilidir. Bu yeni sözcüklerin ağız metinlerinin söz varlığındaki yeri ve sıklığı tespit edilirse yazı dilinin ve teknolojinin ağızlara yapmış olduğu etkiye dair birtakım çıkarımlarda bulunmak mümkün olacaktır. Bu düşünceden hareketle bu çalışmada Türkiye Türkçesi ağızlarından temsilî olarak seçilen dört örnek ağız çalışmasının söz varlığı yeni sözcükler üzerinden değerlendirilmiştir. Batı Grubu ağızlarından Yalova ili yerli ağzı, Doğu Grubu ağızlarından Yusufeli ağzı, Kuzeydoğu Grubu ağızlarından Arhavi ilçesi Derecik köyü ağzı ve Rumeli ağızlarından Lüleburgaz ağızları üzerine yapılmış çeşitli lisansüstü tez çalışmalarından yola çıkılarak bu dört örnek ağız bölgesi söz konusu bağlamda karşılaştırmaya tabi tutulmuştur. Bu karşılaştırmalar sonucunda, örnekleme dâhil olan tüm yaş, cinsiyet ve tahsil gruplarına mensup kaynak kişilerin ölçünlü dilden benzer oranlarda etkilendiklerine dair birtakım veriler ortaya konmuştur.

\section{Anahtar kelimeler}

Türkiye Türkçesi Ağızları, Yeni Sözcük Türetme, Sözcük Canlandırma.

\section{ABSTRACT}

Since the interaction that revealed as a result of advanced technology and the mass media reaching almost every corner of the regions where Turkish dialects are spoken begins to spread in these dialects intensively, Turkish dialectology has been mentioned in many sources. However, while listing the characteristics that dialect compilations should have in source people, the qualifications such as educational status, not leaving the region, age, having the dialect characteristics of the region, gender, occupation, and communication status with metropolitan settlements were brought into the forefront. Because these qualities have been thought to have significant effects on how much the mentioned interaction will reflect on the dialect. At this point, in order to test the relevant thoughts with a scientific method, attempting to measure the impact of new words which were derived or revived from Turkish after the 1930s on the dialectical data, can provide the leading data. Because the literary language, mass media and technology are extremely effective in transferring newly derived words into the folk speech. The reason is that the written language, mass media and technology have been extremely effective in transmitting newly derived words into the public language. If the place and frequency of these new words in the vocabulary of dialectical texts are determined, it will be possible to make some inferences about the effect of written language and technology on dialects. With reference to this idea, in this study, the vocabulary of four sample dialects selected representatively from Anatolian and Rumelian dialects were evaluated over new words. Based on various graduate thesis conducted on Yalova Province Local Dialect from Western Group Dialects, Yusufeli Dialect from Eastern Group Dialects, Arhavi County Derecik village Dialect from Northeast Group Dialects and Lüleburgaz Dialect from Rumeli Dialects, these four sample dialects have been compared in the relevant context.

\section{Keywords}

Dialects of Turkish, Derivation of New Words, Revival of Words. 


\section{GíRIŞ}

Türkçede sözcük hazinesini geliştirme yöntemleri olarak türetme (ekleme, birleştirme, örnekseme, ses değiştirme), derleme ve tarama, ödünçleme, eğretileme, özel adları varlık veya kavram adı olarak kullanma ve kısaltma gibi yöntemler sıralanabilir (Alibekiroğlu, 2017, s. 4445). Türk dili eklemeli bir dil olduğundan kelime türetiminde en çok başvurulan yol tabii olarak ekleme yöntemi olmuştur (Balyemez, 2018, s. 243). Birleştirme ile derleme ve tarama yöntemleri de yine ön plana çıan tercihlerdendir.

Bu noktada, Türkiye Türkçesi ağızlarının, söz varlığı bakımından bilim diline ve ölçünlü dile önemli katkılar yaptığını hatırlatmakta fayda vardır (Şahin, 2019). Türetimde eklerin yanlış kullanımı (Bayar, 2004; Bulak, 2013), kapalı gövdelerden sözcük türetimi (Balyemez, 2018), Türkçe sözcüklere Batı kaynaklı ön ekler getirilerek yeni terim türetimi (Çelik, 2018a) vb. birtakım tartışmalı yönelimler morfolojik sorunları beraberinde getirmiştir. Dilimize geçen yabancı ön ekli kelimelere Türkçe karşılıklar bulunması sırasında karşımıza çıkan ve ilk anda ön ekli kelime olduğu izlenimini uyandıran birleşik kelimeler (Şahin, 2006, s. 67) ile Türkiye Türkçesinde kelime olarak kullanılan Batı kaynaklı ön ekler (Ersoylu, 1993; Çelik, 2015) bahsi geçen ön ekli türetimlerle karıştırılmamalıdır.

Bu çalışmada "yeni sözcük" terimi ile Cumhuriyet'in ardından belli bir tarihten başlayarak ölçünlü dilde kullanıma sokulan sözcükler kastedilmektedir. Osmanlı'da III. Selim devrinde başlayan Batılılaşma akımı ve ardından Tanzimat hareketi ile yazı dilinin sadeleştirilmesi çalışmaları gündeme gelmiştir. Ancak Tanzimat devrinden Cumhuriyet öncesine değin süren dilin sadeleştirilmesi denemeleri arzulanan başarıyı yakalayamamıştır.

Cumhuriyet'in ilanından sonra Mustafa Kemal Atatürk önderliğinde konuyla ilgili sistemli atılımlar gerçekleştirilmiştir. 1928 yılı yılında yeni Türk yazısının kabul edilmesiyle hız kazanan dilde sadeleşme süreci, 1932 yılında Türk Dili Tedkik Cemiyeti'nin kurulmasıyla yoğun gelişmelerin yaşanacağı bir döneme girmiştir.

26 Eylül-6 Ekim 1932 tarihleri arasında I. Türk Dil Kurultayı toplanmış ve dil konusunda yapılacak olan sistematik çalışmaların programı düzenlenmiştir. 1933 yılında Türk Dili Tedkik Cemiyeti tarafından halk ağzından söz derleme seferberliği başlatılmış ve bunun sonucunda 125 bini aşkın fiş kayıt altına alınmıştır. Yine aynı yıl yabancı sözcüklere karşılık bulunması için Kurum tarafından bir anket düzenlenmiş ve 1382 Arapça ve Farsça sözcüğe karşılık aranmıştır. 1934 yılında çıkarılan Osmanlıcadan Türkçeye Söz Karşılıkları Tarama Dergisi de Türk Dili Tedkik Cemiyeti'nin konuyla ilgili önemli atılımlarından biridir. 1934 yılında II. Türk Dil Kurultayı toplanır ve Cemiyet'in ismi “Türk Dili Araştırma Kurumu” olarak değiştirilir. Bu kurultayda ele alınan konulardan birisi de terimler konusu olur. 25 Mart 1935'te Osmanlicadan Türkçeye Cep Kılavuzu, 19 Temmuz 1935'te Türkçeden Osmanlıcaya Cep Kılavuzu yayımlanır. 1936 yılında III. Türk Dil Kurultayı toplanır ve kurumun adı "Türk Dil Kurumu” olarak değiştirilir. Bu kurultayda okul terimleri üzerinde bilhassa durulmuştur. 1940'larda özleştirme işi tekrar ele alınarak çok sayıda yabancı sözcük yerini Türkçe köklerden yapılma sözcüklere bırakır, çalışmalarına uzun süredir devam edilen Türkçe Sözlük tamamlanır. Dilde özleşme hareketi 1930'lu yıllardan sonra özellikle 1940'lı yıllarda ivme kazanmış ve günümüze değin konu hakkında çeşitli çalışmalar yapılmıştır. Bu çalışmalar esnasında dil açısından uygun ve doğru 
kullanımların yanı sıra şekil ve anlamca hatalı birçok yapı da Türk diline girmiştir (Korkmaz, 1963; TDK, 1972; Bayar, 2006).

\section{AMAÇ, YÖNTEM VE SINIRLILIKLAR}

$\mathrm{Bu}$ çalışmanın, “Coğrafya ve kaynak kişilerle bağlantılı nitelikler, ağızların ölçünlü dille etkileşimine hangi oranda tesir etmiştir?”, “Ölçünlü dil ve teknolojinin ağızlara yapmış olduğu etki ne boyuttadır?" gibi araştırma soruları vardır. Çalışmanın amacı ise bu soruların yanıtlarına dair bazı veriler sunabilecek olması dolayısıyla Türkiye Türkçesinde 1930'lu yıllardan sonra türetilen veya canlandırılan yeni sözcüklerin ağız metinlerine etkisinin bir örneklem üzerinden ölçülmesidir. Çalışma yapılırken ağız metinleri ile karşılaştırılmaya tabi tutulan eser Bayar'ın (2006) Açıklamalı Yeni Kelimeler Sözlüğü olmuştur. Bu sözlügün konusu 1930'lu yıllarda bilhassa Türk Dili Tedkik Cemiyetince (Bugünkü adıyla "Türk Dil Kurumu”) yürütülen çalışmalar nihayetinde gerek şahısların türettiği gerekse gazete ve dergilerce yapılan anketlerle belirlenen Arapça ve Farsça sözcüklere karşılık olarak türetilmiş olan yeni sözcüklerdir. Bunlarla beraber eskiden de kullanılıp sonradan canlandırılan, Türkiye Türkçesi ağızlarından ölçünlü dile aktarılan ve yabancı sözcük karşılı̆̆ı olmayıp belirli bir kavramı karşılayan sözcükler de aynı eser kapsamında ele alınmıştır, 1935 yılında yayımlanan Türkçeden Osmanlıcaya ve Osmanlıcadan Türkçeye Cep Kılavuzları söz konusu kelimelerin ana kaynağı olarak kullanılmıştır. Eserde modern Türkçede yer alan sözcüklerden hangilerinin yeni kelime olduğu, bunların gramer yapıları, kullanım sahaları tespit edilmiş konuyla ilgili bir literatür taraması yapılarak bu sözcükler hakkındaki dil tartışmalarına yer verilmiştir (Bayar, 2006, s. 8-9).

Bu çalışmada ise Türkiye Türkçesi ağızlarından temsilî olarak seçilen dört örnek ağız çalışmasının söz varlığı yeni sözcükler üzerinden değerlendirilmiştir. Batı Grubu ağızlarından Yalova ili yerli ağzı (Çelik, 2018b), Doğu Grubu ağızlarından Yusufeli ağzı (Koruk, 2019), Kuzeydoğu Grubu ağızlarından Arhavi ilçesi Derecik köyü ağzı (Bayramin, 2014) ve Rumeli ağızlarından Lüleburgaz ağızları (Mutlu, 2018) üzerine yapılmış çeşitli lisansüstü tez çalışmalarından ve bu çalışmalardan üretilen yayımlardan yola çıkılarak bu dört örnek ağız bölgesi söz konusu bağlamda karşılaştırmaya tabi tutulmuştur. Bu ağız çalışmaları örneklem için seçilirken, derleme metotlarının istenen verilere ulaşmayı kolaylaştıracak şekilde uygulanmış olup olmaması ve çalışmaların güncelliği temel kriter olarak değerlendirilmiştir. Çalışmayla birlikte, kaynak kişilerin yukarıda bahsedilen niteliklerinin yeni sözcüklerin ağızlara yansımasını etkileyip etkilemediği ve etkilediyse hangi açılardan etkilediği irdelenmiştir. Bu yapılırken; grafikler, tablolar ve çeşitli görseller aracılığıyla bulgular çalışmaya yansıtılmış, veriler anlaşılır kılınmaya çalışılmıştır. Böylelikle yeni kelimelerin ağızlara olan etki derecesi, yeni kelimelerden hangilerinin ağızlarda daha çok tercih edildiği, yazı dilinin ağızlara tesir düzeyi gibi pek çok konuda fikir verebilecek bir örneklem ortaya konmuştur. İncelenen çalışmalarda yer alan ağız metinlerinin kaynak kişileri genelde yaşlı kişilerdir ve bu kişilerin tahsil durumu çoğunlukla okuma yazma bilmeme ya da ilkokul seviyesindedir. Genç ve tahsilli kaynak kişilerden derlenen metinlerin boyutu ve kelime sayısı da yaşlı kişilere oranla sınırlıdır. Yaş ve tahsil durumundaki bu benzerlik, bahsi geçen bağlamda karşılaştırmalar yapılırken araştırma evreni açısından bir kısıtlılık olarak ortaya çıkmaktadır. Bu kısıtlılık, karşılaştırma yönünün kaynak kişilerin niteliklerine uygun şekilde düzenlenmesiyle giderilmeye çalışılmıştır. Türkiye Türkçesi ağızları çok geniş coğrafyalarda 
konuşulan ve söz varlığı açısından son derece zengin ağızlardır. Örneklem olarak seçilen dört ağız yöresinin söz varlı̆̆ı bu ağızlar içinde çok küçük bir alanı temsil etmektedir. Ancak çalışmanın boyutu böyle bir kısıtlandırmayı gerekli kılmıştır. Bu kısıtlılık ise her bir ana gruptan seçilen ağız çalışmalarının bu grupların karakteristik özelliklerini bünyesinde barındırması ve derleme metotlarının istenen verilere ulaşmayı kolaylaştıracak şekilde uygulanmış olup olmasına dikkat edilmesi sonucu mümkün olan ölçüde devreden çıkarılmaya çalışılmıştır. Araştırma, ilgili konuda tutarlı ve genel veriler ihtiva edecek şekilde düzenlenmiş, verilerin istatistiksel analizi ile yeni kelimelerin ağızlara etkisi konusunda gerçekçi çıkarımlar yapmaya olanak sağlayacak çıktıları araştırmacıların ilgisine sunmayı hedeflemiştir.

\section{BULGULAR}

Dört ağız çalışmasında yer alan metinlerdeki incelenen 127.416 sözcükten 557 adeti yeni kelime olarak tespit edilmiştir. Bu da toplam sözcük sayısının \%0,43'üne tekabül eder. Bu yeni sözcüklerden 30 tanesi derleyicilerin sordukları sorularda geçen ve kaynak kişilerce sorulara cevaben söylenmiş yapılardır.

Yeni kelimelerin ağız metinlerine oranları ayrı ayrı incelendiğinde ise şu sonuçlarla karşılaşılır: Yusufeli ağzında incelenen 18.312 sözcükten 115 tanesi $(\% 0,62)$ yeni sözcüktür. Lüleburgaz ağızlarında incelenen 12.681 sözcükten 68'i $(\% 0,53)$, Derecik ağızlarında incelenen 27.035 sözcükten 194'ü $(\% 0,71)$ ve Yalova ili yerli ağzında incelenen 69.388 sözcükten 180 'i $(\% 0,25)$ yeni kelime olarak saptanmıştır.

Tablo 1. Incelenen Metinlerdeki Yeni Sözcüklerin Toplam Sözcüklere Oranı

\section{incelenen Metinlerdeki Yeni söxcüklerin Toplam Söxcülslere Oranı}

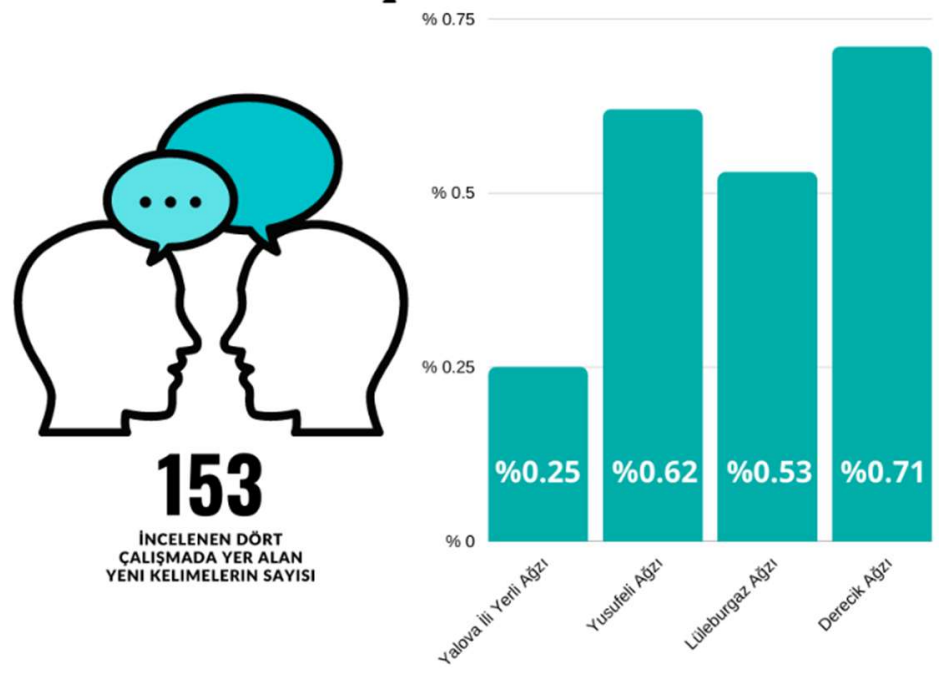

İncelenen dört çalışmada yer alan birbirinden farklı yeni kelimelerin sayısı ise 153'tür. Bu 153 kelimeden 16 adedi $(\% 10,5)$ fiil ve 137 adedi $(\% 89,5)$ isim ve isim soylu sözcüklerdir. 
Tablo 2. İncelenen Metinlerde Geçen Yeni Sözcüklerin Sözcük Türü İstatistikleri

\section{incelenen Metinlerde Geçen Yeni Söxcülklerin Söxcülk Türü istatistilkleri}

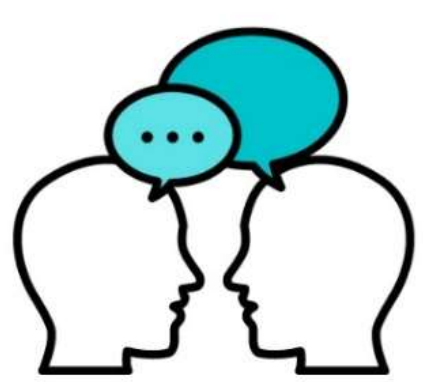

153

INCELENEN DÖRT CALISMADA YER ALAN

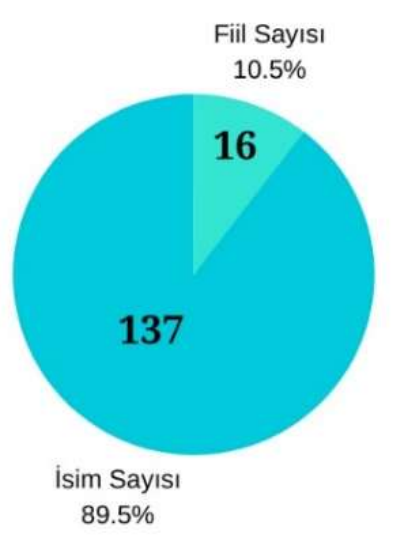

Metinler dâhilinde Yalova ili yerli ağzında 74 farklı yeni sözcük, Derecik ağzında 80 farklı yeni sözcük, Yusufeli ağzında 47 farklı yeni sözcük ve Lüleburgaz ağızlarında 37 farklı yeni sözcük gözlenmiştir. Bahsi geçen yeni sözcüklerden birçoğunun köy dışı yaşamla yahut devlet kurumlarına bağlı resmî isimlendirmelerle bağlantılı terimler olduğu görülür. Örnek vermek gerekirse metinlerde rastlanan 153 farklı yeni sözcükten 15 tanesi askerlikle ilgili terimdir.

Tablo 3. Incelenen Çalışma Başına Düşen Farklı Yeni Sözcük İstatistikleri

\section{incelenen Çalışma Başıma Düşen Farkh Yeni Sözcük istatistikleri}

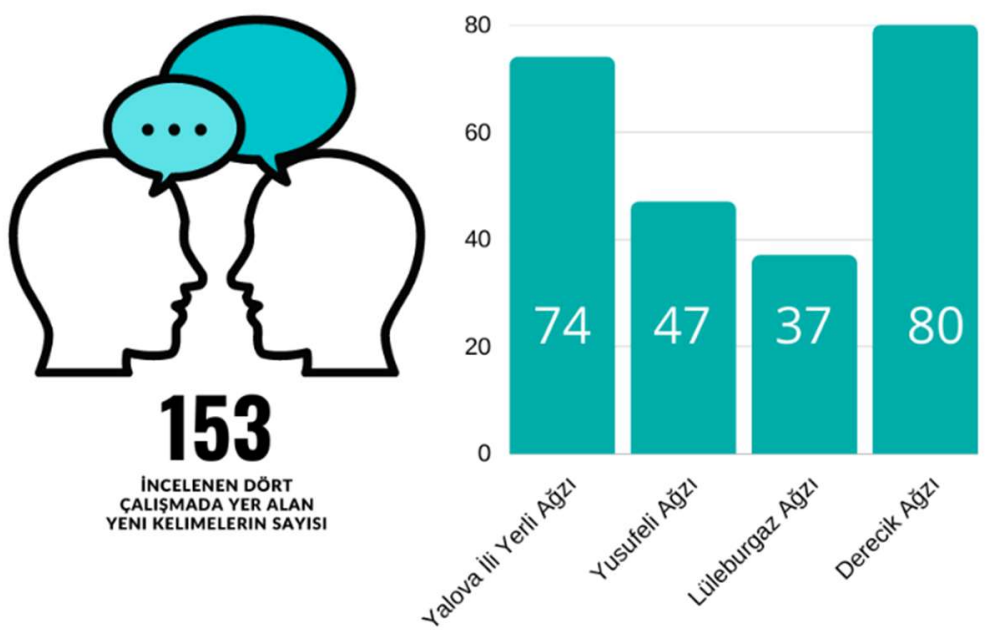

Bu yeni sözcükler arasında en çok kullanılanlardan bazıları ile bunların kendileri karşılığında türetildikleri eski sözcüklerin ağızlardaki kullanımları ise şu şekildedir: Yeni sözcük: okul (47 ayrı kullanım), eski sözcük: mektep (1 ayrı kullanım); yeni sözcük: durum (30 ayrı kullanım), 
eski sözcük: hâl (6 ayrı kullanım), eski sözcük: vaziyet (11 ayrı kullanım); yeni sözcük: türlü (28 ayrı kullanım), eski sözcük: muhtelif (0 ayrı kullanım); yeni sözcük: genel (24 ayrı kullanım), eski sözcük: umumi (0 ayrı kullanım); yeni sözcük: subay (21 ayrı kullanım), eski sözcük: zabit (0 ayrı kullanım); yeni sözcük: öğretmen (17 ayrı kullanım), eski sözcük: muallim (0 ayrı kullanım); yeni sözcük: emekli (16 ayrı kullanım), eski sözcük: mütekait (0 ayrı kullanım), tekaüt (0 ayrı kullanım); yeni sözcük: geçim (15 ayrı kullanım), eski sözcük: maişet (0 ayrı kullanım); yeni sözcük: özel (15 ayrı kullanım), eski sözcük: hususi (1 ayrı kullanım); yeni sözcük: ekim (ay), (14 ayrı kullanım) eski sözcük: teşrinievvel (0 ayrı kullanım).

Bu noktada çalışmada yer alan tüm yeni sözcüklerden 30 tanesinin derleyicilerin sordukları sorularda geçen ve kaynak kişilerce sorulara cevaben söylenmiş yapılar olduğunu hatırlatmakta fayda vardır. Böyle sözcükler çalışmanın "Ek 1 - İncelenen Çalışmalardaki Yeni Sözcüklere Dair Bilgiler" kısmında ilgili tablonun “Notlar” başlığı dâhilinde belirtilmiştir.

İncelenen dört çalışmada yer alan 153 farklı yeni sözcükten 89 tanesi ağızlardan birinde, 38 tanesi ikisinde, 18 tanesi üçünde, 8 tanesi ise dördünde birden geçmektedir. İlgili sözcükler "Ek-1"'de yer alan tabloda listelenmiştir. Bu çalışmalardaki metinlerin dördünde birden geçen sözcükler şunlardır: dönem, geçim, genel, okul, öğretmen, özel, türlü, yaşam.

Tablo 4. Incelenen Çalışmalardaki Yeni Sözcüklerin Kullanıldıkları Ağız İstatistikleri

\section{incelenen Çalışmalardaki Yeni Söxcüklerîn Kulanıldılkları Ağıx istatistikleri}

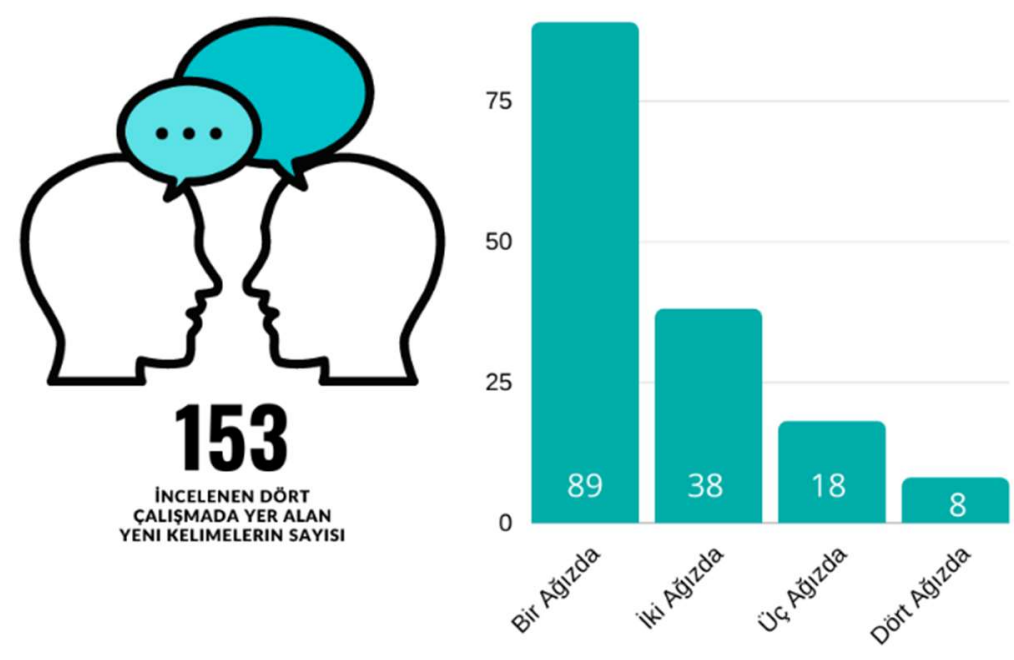

İncelenen dört çalışmada yer alan 153 farklı yeni sözcükten 41 tanesi $(\% 26,79)$ yeniden canlandırılmış sözcük iken 5 tanesi $(\% 3,26)$ ise halk ağzından ölçünlü dile kazandırılan sözcüklerdendir. 
Tablo 5. İncelenen Metinlerdeki Yeniden Canlandırılan ve Halk Ağzından Alınan Yeni Sözcükler

\section{incelenen Metinlerdeki Yeniden Canlandırılan ve Hahl Ağrindan Alnan Yeni Söxcükler}

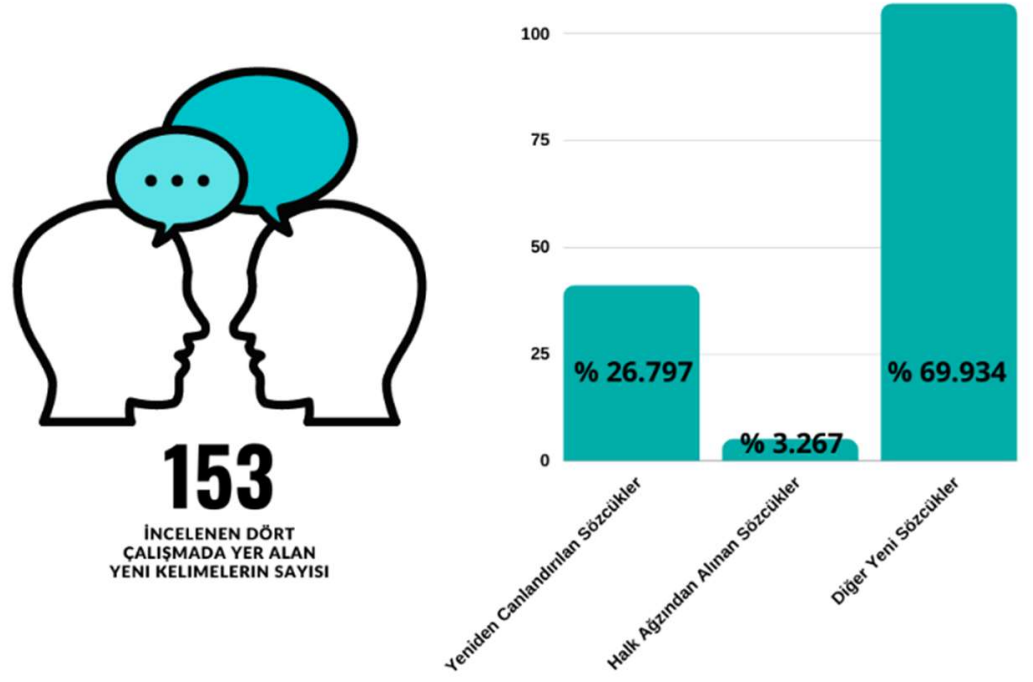

İncelenen dört eserdeki kaynak kişilerin cinsiyetleriyle ilgili istatistiklere bakıldığında Yalova ili yerli ağzı kapsamında yapılan derlemelerde 23 erkek, 20 kadın kaynak kişi (\%53-\%47); Yusufeli ağzında 18 erkek, 12 kadın kaynak kişi (\%60-\%40); Lüleburgaz ağılarında 9 erkek, 5 kadın kaynak kişi (\%64-\%36) ve Derecik ağzında 7 erkek, 16 kadın kaynak kişinin (\%30-\%70) yer aldığı görülür. Bu dört çalışmadaki toplam kaynak kişi sayısı 57 erkek, 53 kadın kaynak kişi (\%52-\%48) olarak karşımıza çıkar.

Tablo 6. İncelenen Çalışmalarda Kaynak Kişilerin Cinsiyetleri

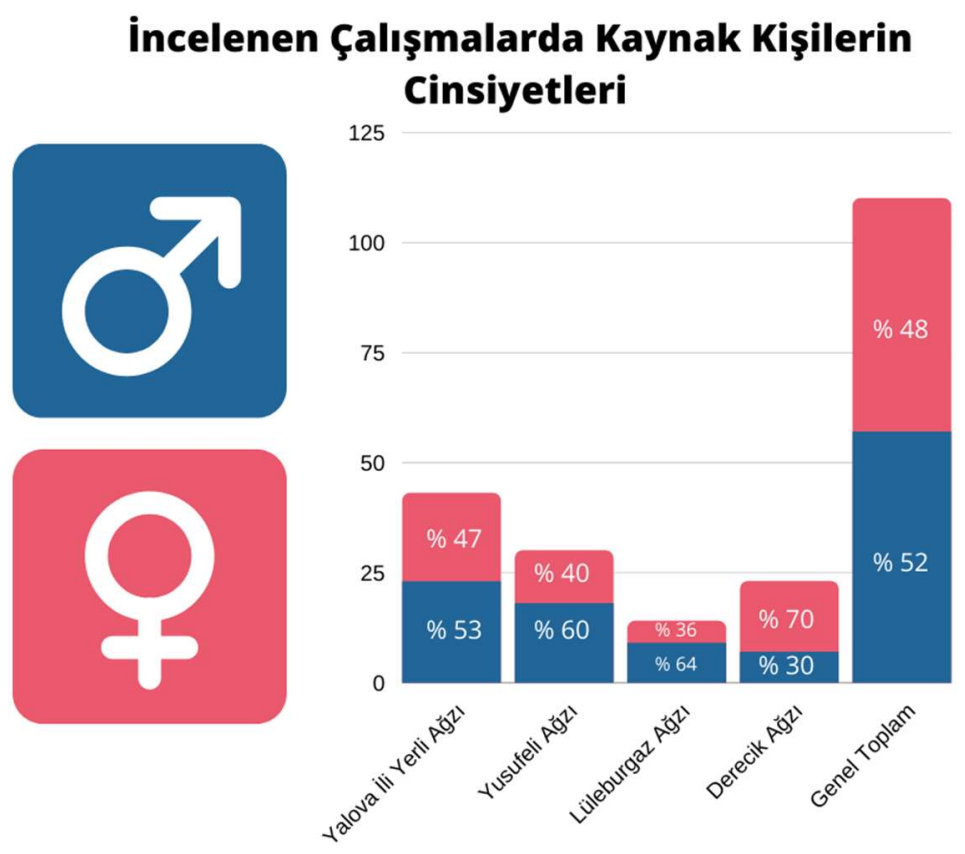


Bu dört çalışmadaki kaynak kişilerin yaş ortalamaları Yalova ili yerli ağzında 76,90; Yusufeli ağzında 76,13; Lüleburgaz ağızlarında 68,92 ve Derecik ağzında 63,04 şeklindedir. Genel yaş ortalaması ise $72,58^{\prime}$ dir.

Tablo 7. İncelenen Çalışmalarda Kaynak Kişilerin Yaş Ortalamaları

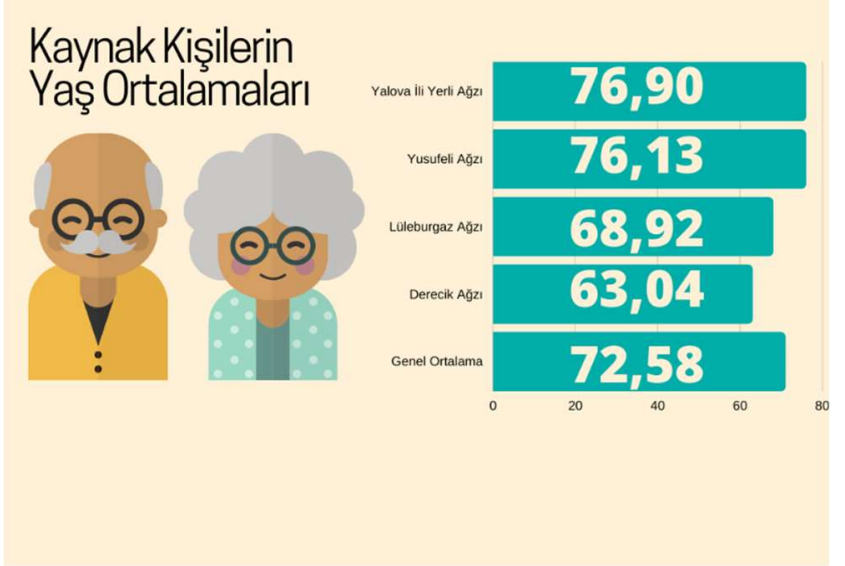

Yeni kelimeleri en az bir kere kullanan kaynak kişilerin yaş ortalaması Yalova ili yerli ağzında 76,578; Yusufeli ağzında 75,40; Lüleburgaz ağızlarında 65,07; Derecik ağzında 65,57 iken hiç kullanmayanların yaş ortalaması Yalova ili yerli ağzında 75,4; Yusufeli ağzında 75; Lüleburgaz ağızlarında 54; Derecik ağzında 56,25'tir. Genel ortalamaya bakıldığında yeni kelimeleri en az bir kere kullanan kaynak kişilerin yaş ortalaması 73,22 iken yeni kelimeleri hiç kullanmayan kaynak kişilerin yaş ortalaması 67,76 şeklindedir.

Tablo 8. İncelenen Çalışmalarda Yeni Kelimeleri En Az Bir Kere Kullanan ve Hiç Kullanmayan Kaynak Kişilerin Yaş Ortalamaları

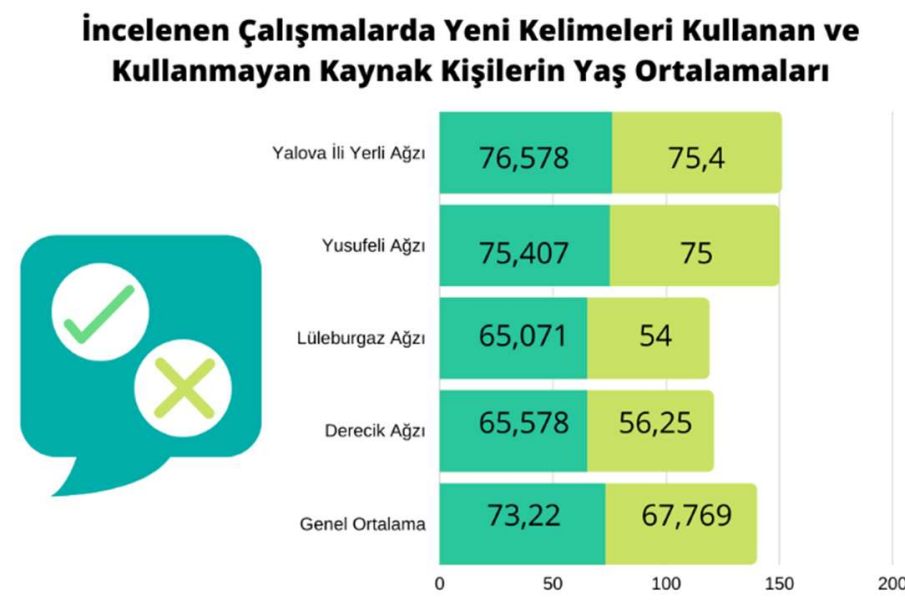


İncelenen çalışmalarda yeni kelimeleri en az bir kere kullanan ve hiç kullanmayan kaynak kişi sayılarının birbirine oranı ise aşağıdaki gibidir: Yalova ili yerli ağzı "kullanan": \%88 (38 kişi) "kullanmayan": \%12 (5 Kişi); Yusufeli ağzi "kullanan": \%90 (27 Kişi) - “kullanmayan": \%10 (3 Kişi); Lüleburgaz ağızları "kullanan": \%93 (13 Kişi) - "kullanmayan": \%7 (1 Kişi) ve Derecik ağzı "kullanan": \%88 (19 Kişi) - “kullanmayan": \%12 (4 Kişi). Genel olarak kullananların kullanmayanlara oranı ise $\% 89^{\prime}$ a $\% 11^{\prime}$ dir.

Tablo 9. Incelenen Çalışmalarda Yeni Kelimeleri En Az Bir Kere Kullanan ve Hiç Kullanmayan Kaynak Kişiler

\section{Incelenen Çalışmalarda Yeni Kelimeleri Kullanan ve Kullanmayan Kaynak Kişiler}

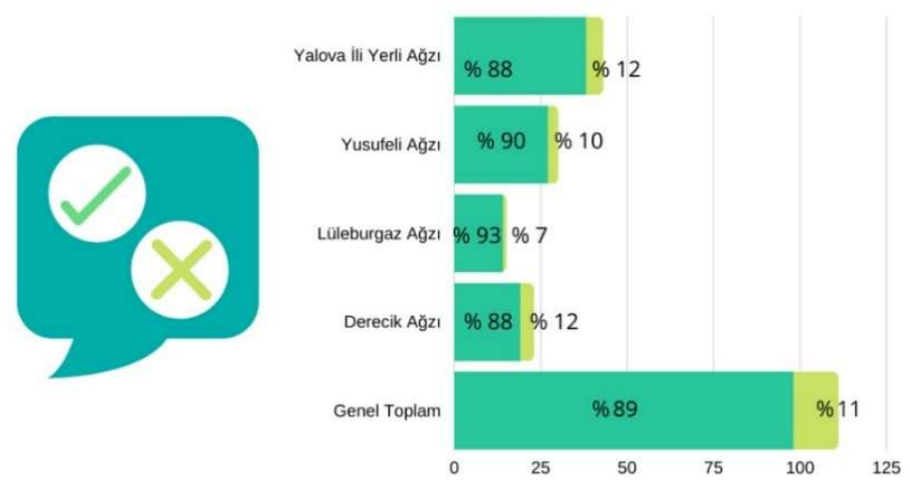

Yeni kelimeleri en az bir kere kullanan ve hiç kullanmayan kaynak kişilerin genel cinsiyet istatistiklerinde bakıldığında kullananlardan \%47,42'sinin kadın (46 Kişi) ve \%52,57'sinin erkek (51 Kişi); kullanmayanlardan ise \%46,15'inin erkek (6 Kişi) ve \%53,84'ünün kadın (7 kişi) olduğu görülür.

Tablo 10. Incelenen Çalışmalarda Yeni Kelimeleri En Az Bir Kere Kullanan ve Hiç Kullanmayan Kaynak Kişilerin Cinsiyet İstatistikleri

\section{İncelenen Çalışmalarda Yeni Kelimeleri Kullanan ve Kullanmayan Kaynak Kişilerin Cinsiyet istatistikleri}
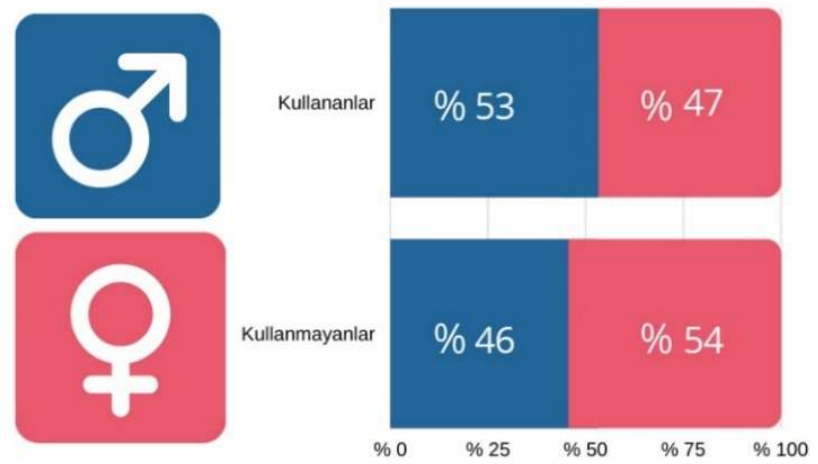
Yukarıdaki istatistiklere kaynaklık eden veriler araştırmacıların yararlanabilmesi adına "Yeni Sözcük”, “Eski Sözcük / Anlam”, “Ağı Örneklemindeki Kullanım” ve "Notlar" düzeninde tablolaştırılarak çalışmanın sonundaki Ek-1 kısmında dikkatlere sunulmuştur.

\section{TARTIŞMA, SONUÇ VE ÖNERILER}

İncelenen metinlerdeki toplam sözcük sayısının \%0,43’ü “yeni sözcükler”dir. Ağız başına düşen oranlar ise $\% 0,25$ ila $\% 0,71$ arasında değişir. Bunlar düşük oranlar gibi gözüküyorsa da dört ağız bölgesinden derlenen 153 farklı yeni sözcükten en az birini kullanan kaynak kişilerin istatistiklerine bakıldığında bu tablonun değiştiği görülür. Bu sözcükleri en az bir kere kullanan kaynak kişilerin oranı \%89 iken hiç kullanmayanların oranı \%11'de kalır. Ağız temelindeki istatistikler ele alındığında da bu sözcükleri kullananların oranlarının \%88 ila \%93 arasında seyrettiği saptanır. Bu veriler göstermektedir ki örneklemdeki tüm ağız bölgelerinde, anlamlı değişiklikler bulundurmaksızın yeni sözcükler kaynak kişilerin ağızlarına benzer ölçülerde etkide bulunmuştur. Her 10 kaynak kişiden yaklaşık 9'u konuşmalarında yeni sözcükleri kullanmıştır. Bu da hem yeni kelimelerin genel dile yerleşmedeki başarısını göstermesi hem de ölçünlü dilin ağızlara etkisinin ne boyutta olduğuna dair fikir vermesi açısından önemlidir. Metinler dâhilinde Yalova ili yerli ağzında 74 farklı yeni sözcük, Derecik ağzında 80 farklı yeni sözcük, Yusufeli ağzında 47 farklı yeni sözcük ve Lüleburgaz ağızlarında 37 farklı yeni sözcük görülmesi de benzer bilgiler sunar. Bu yeni sözcükler arasında en çok kullanılan örneklerin kendileri karşıllğında türetildikleri eski sözcüklerin ağızlardaki kullanımlarına oranla çok daha fazla tercih edilmiş olması ve hatta çoğunlukla eski karşılıklarının ağızlarda hiçbir şekilde bulunmaması, birçok yeni sözcüğün türetilme amacına ulaştığına hatta bu sözcüklerin ölçünlü dilin sınırını aşarak ağız konuşurlarının dilinde dahi açık bir şekilde yer edindiğine işaret eder. Söz konusu 153 farklı yeni sözcükten 64 adedinin birden fazla ağızda gözlemlenmesi de aynı doğrultuda bir göstergedir. Bu çalışmalardaki metinlerin dördünde birden geçen sözcükler olan; “dönem, geçim, genel, okul, öğretmen, özel, türlü, yaşam” sözcüklerinden "dönem”, “geçim”, “okul” ve "öğretmen” gibi yapılar köy dışı yaşamla yahut devlet kurumlarına bağlı resmî isimlendirmelerle bağlantılı yapılarken "genel", "özel”, "türlü", "yaşam” gibi sözcükler daha geniş kullanımlı ifadelerdir. Bu 153 farklı yeni sözcükten 41 tanesinin $(\% 26,79)$ yeniden canlandırılmış sözcük ve 5 tanesinin $(\% 3,26)$ de halk ağzından ölçünlü dile kazandırılan sözcüklerden olması bunlardan bazılarının belki de söz konusu ağızlarda ölçünlü dilin etkisi dışında eskicil şekilde de barınmış olabileceğini düşündürmesi açısından ilgi çekicidir. İncelenen metinlerde geçen yeni sözcüklerin sözcük türü istatistikleri Türkçede yer alan tüm yeni kelimelerin istatistikleriyle paralel şekilde isim ve isim soylu sözcüklerin ağırlıkta olduğu, fiillerin ise azınlıkta olduğu bir yönelim izler. Bu çalışmalardaki 153 farklı yeni sözcükten 16 adedi $(\% 10,45)$ fiil; 137 adedi $(\% 89,54)$ isim ve isim soylu olarak kaydedilmiştir. Dilin doğası gereği alıntı sözcükler büyük çoğunlukla fiillerden ziyade isimler karşılığında ödünçlendiğinden bunların yerine türetilen yeni sözcükler de benzer bir sıklık göstermiştir.

Ağız derlemelerinin kaynak kişilerinde bulunması gereken özellikler sıralanırken; öğrenim durumu, yöreden ayrılmamış olma, yaş, yörenin ağız özelliklerini taşıma, cinsiyet, meslek, büyük yerleşim merkezleriyle iletişim durumu gibi nitelikler ön plana çıkarılır (Demir, 1998). $\mathrm{Bu}$ araştırmanın kaynak kişileri benzer eğitim durumlarından olduğu için elde edilen verilerle bu konuda çıarımlar yapmak güçtür. Ancak bu veriler, yaş unsurunun yeni kelimelerin 
ağızlardaki kullanımıyla ve dolayısıyla kaynak kişilerin bu konudaki etkileşim düzeyiyle ilişkisi konusunda birtakım ipuçlarını bünyelerinde barındırmaktadır. İncelenen ağızlardaki kaynak kişilerin yaş ortalamaları ve yeni kelimeleri en az bir kere kullanan ve hiç kullanmayan kaynak kişilerin istatistikleri incelendiğinde Yalova ili yerli ağzı genel yaş ortalaması "76,90", yeni kelimeleri kullananların yaş ortalaması “76,57”, kullanmayanların yaş ortalaması "75,4"; Yusufeli ağzı genel yaş ortalaması "76,13", yeni kelimeleri kullananların yaş ortalaması "75,40", kullanmayanların yaş ortalaması "75"; Lüleburgaz ağızları genel yaş ortalaması "68,92", yeni kelimeleri kullananların yaş ortalaması “65,07", kullanmayanların yaş ortalaması "54"; Derecik ağzı genel yaş ortalaması "63,04", yeni kelimeleri kullananların yaş ortalamas1 "65,57", kullanmayanların yaş ortalaması " 56,25 "; genel ortalamada yeni kelimeleri kullananların yaş ortalaması "73,22", kullanmayanların yaş ortalaması “67,76" şeklinde ortaya çıkar. Bu verilere göre tüm ağızlarda yeni kelimeleri en az bir kere kullanan kaynak kişilerin yaş ortalamaları kullanmayanlara oranla daha yüksek gözükmektedir. Ancak bu veriler yanıltıcı olmamalıdır. Tüm ağızlarda yaşları küçük kaynak kişilerden yapılan derleme sayısı az tutulmaya çalışılmıştır. Bu kişilerden derleme yapıldığında ise derlenen metinlerin kısa tutulması eğilimi gözlenmektedir. Dolayısıyla az sayıdaki sözcük örneklemi içinde yeni kelimelerin derlenmesi her zaman mümkün olmamaktadır. $\mathrm{Bu}$ da yeni kelimeleri hiç kullanmayan kaynak kişi istatistiklerine yansımakta ve bu kişilerin yaş ortalamasını daha düşükmüş gibi göstermektedir. Bunun istatistiklerine daha az yansıdığı Yalova ili yerli ağzı ve Yusufeli ağzına bakıldığında tüm yaş kategorilerinde oranların birbirine çok yakın olduğu, söz konusu durumun istatistiklere daha çok yansıdığı Lüleburgaz ağızları ve Derecik ağzında ise oranların yaşı küçükler lehine birbirinden biraz daha uzaklaştığı görülür. Genç kaynak kişilerden daha uzun metinler derlendiğinde yeni kelimelerin bu metinlerde de benzer sıklıkta yer aldığ1 tespit edilebilmektedir. Tüm bu veriler bu bağlamda değerlendirildiğinde aslında her yaş grubunda yeni sözcüklerin kullanıldığı, en azından orta yaş ve yaşlı kimselerin bu kelimeleri kullanım sıklığı hususunda birbirinden çok büyük farklılıklar taşımadığ Bu çalışma, ağız metinlerindeki kaynak kişilerin yaşları dolayısıyla 18 - 40 yaş grubundaki kimselerin istatistiklerini yansıtmada eksik kalsa da günlük yaşamdan yapılan gözlemlere dayanılarak gerek tahsil durumu ve gerekse yaşayış ve etkileşim fazlalığı dolayısıyla bu sıklıkların söz konusu yaş ortalamalarında daha yüksek oranlarda olacağı tahmin edilebilir. Konu "yöreden ayrılmamış olma" açısından değerlendirildiğinde ağızların kaynak kişilerinin mümkün olduğu ölçüde yöreden ayrılmamış olan kimselerden seçilmeye çalışıldığı hatırlanmalıdır. Tabii ki bu her zaman mümkün olmamıştır. Kişilerin yörelerinden ayrı kaldığı sürelerin etkileri çok büyük oranlarda değilse de yeni kelimelerin kullanım sıklıklarına yansımıştır. Örneğin tüm ağızlar içinde yeni sözcükleri en fazla sayıda kullanan kaynak kişi, Yalova ili yerli ağzı konuşuru “O.G." 67 yaşındadır. Bu kişinin yaş ortalamasının kaynak kişilerin genel ortalamasının altında olduğu, iki dönem muhtarlık yapan ve şehirle ilişki içinde olan bir kişi olduğu ve de cinsiyetinin erkek olduğu görülmektedir.

Cinsiyet ve yeni sözcük kullanımı ilişkisine göz atıldığında kadınlarla erkekler arasında, genel beklentinin aksine büyük farklar olmadığı da saptanmıştır. Oranlar erkekler yönünde az miktarda yüksek gözükse de aradaki farkl1lıklar çok küçüktür. Söz konusu metinlerdeki kaynak kişilerin cinsiyet istatistikleri \%52 erkek \%48 kadın şeklindedir. Yeni kelimeleri en az bir kere kullananlardan \%47'sinin kadın (46 Kişi) ve \%53'ünün erkek (51 Kişi); kullanmayanlardan ise \%46'sının erkek (6 Kişi) ve \%54'ünün kadın (7 kişi) olduğu göz önüne 
alındığında ölçünlü dilden kadınların da erkeklere benzer oranda etkilenmeye başladığ1 çıkarımı yapılabilir. Kaynak kişilerin meslekleriyle ilgili pek çok yeni sözcüğe söz dağarcıklarında yer verdiği de yine bu araştırma dâhilinde gözlenenler arasındadır. Bununla beraber bu yeni sözcüklerden 30 tanesi derleyicilerin sordukları sorularda geçen ve kaynak kişilerce sorulan sorulara cevaben söylenmiş yapılardır. Bu noktada derleyicilerin mümkün olduğu ölçüde konuşurların ağızlarına yakın sözcük dağarcığıyla onlarla iletişim kurmasının önemi ortaya çıkar. Çünkü bu türden kimi kullanımlarda kaynak kişiler ölçünlü dilden uzaklaşma kaygısıyla bazı sözcüklerin anlamlarını tam olarak bilmeseler de derleyicileri taklit yoluna giderek sözcük dağarcıklarını doğru yansıtmayabilmektedir. Buna örnek olarak Yalova ili yerli ağzındaki şu diyalog gösterilebilir; "Derleyici: Bu köye özgü bir geleneğiniz var mı aklınıza gelen? - Kaynak Kişi: yoḲ bizim be yoḲ öle özgür mözgür böle bi şelé yaPmayoz biz hani" (Çelik, 2018, s. 527). Burada derleyicinin kullandığı yeni sözcüğü anlamayan kaynak kişi, bildiği bir başka yeni sözcükle yanıt vermiş ve iki sözcügün birbirine karıştırıldığ1 görülmüştür.

Tüm bu veriler dikkate alınarak bu çalışmanın çıktılarıyla ilgili şu sonuç ve önerilere ulaşılabilir: İncelenen örneklemdeki yeni sözcüklerin toplam sözcüklere oranı \%0.43 ise de her 10 kaynak kişiden yaklaşık 9'u konuşmalarında yeni sözcükleri en az bir kere kullanmıştır, bu ve bu doğrultudaki diğer veriler yeni sözcüklerin ölçünlü dilin yanı sıra Türkiye Türkçesi ağızlarında da kalıcı bir şekil yer edindiğini gösterir. Yaş unsurunun yeni sözcüklerin kullanımına yansıma oranı en azından orta yaş ve üzeri yaş grupları arasında büyük farklılıklar göstermez. Yani yaşlı kimselerin ağızlarında da genel beklentinin aksine yeni kelimeler çok canlı bir şekilde yer alır. Bu da ölçünlü dilin ağızlara etkisi noktasında önemli bir veri ihtiva eder. Benzer bir durum yeni sözcük kullanımların cinsiyete göre dağılımı istatistiklerinde de söz konusudur. Erkek kaynak kişilerle kadın kaynak kişilerin bu sözcükleri kullanım oranları beklentilerin aksine birbirine yakındır. Yani kadın kaynak kişiler de ölçünlü dilden yeni sözcük anlamında neredeyse erkek kaynak kişiler kadar etkilenmiştir. Mesleklere dair sözcükler yeni sözcükler bağlamında ağızların söz dağarcı̆̆ına önemli etkilerde bulunmuş, devlet kurumlarına bağlı resmî isimlendirmelerle bağlantılı terimler de yine ağızların söz dağarcığını yeni sözcük bağlamında etkilemiştir. Meslekleri gereği büyük yerleşim yerleriyle daha çok iletişimde bulunanların ölçünlü dilden etkilenmesi hususu yeni kelimeler aracılığıyla da tanıklanabilmektedir. Yine de hemen her ağız bölgesi, her yaş ve cinsiyet grubu, tahsil durumu yüksek olanların yanı sıra tahsil durumu düşük olanların, ufak oran farklılıkları dışında aralarında çok yüksek farklılıklar olmaksızın ölçünlü dilden kayda değer oranda etkilendikleri yeni sözcükler aracılığıyla ortaya konabilmektedir. Derleyiciler kaynak kişi seçiminde tüm bu etkileşimi göz önünde bulundurmalı, kaynak kişilerden derleme yaparken kullanacakları yöntemi söz konusu etkileşimi asgari düzeye indirecek biçimde seçmelidir. 


\section{KAYNAKÇA}

Alibekiroğlu, S. (2017). Türkçede sözcük türetme yolları. G.Ü. Sosyal Bilimler Dergisi, 1, 35- 46.

Balyemez, S. (2018). Türkiye Türkçesinde kapalı gövde örnekleri. Atatürk Üniversitesi Türkiyat Araştırmaları Enstitüsü Dergisi, 63, 243-266.

Bayar, N. (2006). Açıklamalı yeni kelimeler sözlüğ̈̈u. Ankara: Akçağ Yayınları.

Bayar, N. (2004). Türkçede yanlış türetmeye sebep olan bazı ekler. V. Uluslararası Türk Dili Kurultayı Bildirileri-I, 405-429, Ankara: Türk Dil Kurumu.

Bayramin, N. (2014). Artvin ili Arhavi ilçesi Derecik köyü ă̆zı (inceleme, metinler ve sözvarlı̆̆ı). Yayımlanmamış yüksek lisans tezi, Doğu Akdeniz Üniversitesi, Gazimagusa.

Bulak, Ş. (2013). Türkçenin sadeleştirilmesinde yanlış ek kullanımı veya eklerin yanlış kullanılmasi. The Journal of Academic Social Science Studies International Journal of Social Science, 6(3), 57-76.

Çelik, A. (2015). Türkçede kelime olarak kullanılan batı kaynaklı ön eklerin bugünkü durumu üzerine. Eurasian Academy of Sciences Social Sciences Journal, 6, 82-99.

Çelik, A. (2018a). Türk dilinde bir modernleşme sorunu: türkçe kelimelere batı kaynaklı ön ekler getirilerek türetilen yeni terimler. Dil ve Edebiyat Yazıları içinde. 53-77. Ankara: Bilgin Kültür Sanat Yayınları.

Çelik, A. (2018b). Yalova ili yerli ă̆zı (İnceleme-metinler-sözlük). Yayımlanmamış Doktora Tezi, Uludağ Üniversitesi, Sosyal Bilimler Enstitüsü, Bursa.

Demir, N. (1998). Ağız araştırmalarında kaynak kişi meselesi. 171-180. Dursun Yıldırım Armağamı içinde. Ankara: TDK.

Ersoylu, H. (1993). Batı kökenli ön ek'lerin Türk dilinde kelime olarak kullanılması. Türk Dili Dergisi, 497, 326-334.

Korkmaz, Z. (1963). Türk dilinin tarihî akışı içinde Atatürk ve dil devrimi. Ankara: Ankara Üniversitesi Dil Tarih Coğrafya Fakültesi Yayınları.

Koruk, Ö. (2019). Yusufeli ă̆zı. Yayımlanmamış yüksek lisans tezi, Recep Tayyip Erdoğan Üniversitesi, Sosyal Bilimler Enstitüsü, Rize.

Mutlu, M. (2018). Lüleburgaz ağızları. Yayımlanmamış yüksek lisans tezi, Eskişehir Osmangazi Üniversitesi, Sosyal Bilimler Enstitüsü, Eskişehir.

Şahin, H. (2006). Türkçede ön ek. U.Ü. Fen-Edebiyat Fakültesi Sosyal Bilimler Dergisi, 7(10), 6577.

Şahin, H. (2019). Türkiye Türkçesi ağızlarının söz varlığı bakımından bilim diline katkısı. Oğuztad Ŏ̆uz Türkçesi Araştırmaları Dergisi, 1, 208-214.

TDK (1972). Türk Dil Kurumu'nun 40 yılı. Ankara: Türk Dil Kurumu Yayınları. 


\section{KISALTMALAR}

\begin{tabular}{|c|c|}
\hline Kisaltmalar & Açıklamalar \\
\hline Örn. (AADKA - S.G. K/45) (2) & $\begin{array}{l}\text { Örn. (Ağız Çalışması - Kaynak Kişi Kaynak } \\
\text { Kişinin Cinsiyeti/Kaynak Kişinin Yaşı) } \\
\text { (Sözcüğü Kullanma Sayısı) }\end{array}$ \\
\hline AADKA & Artvin ili Arhavi ilçesi Derecik köyü ağzı \\
\hline LA & Lüleburgaz ağızları \\
\hline TDK & Türk Dil Kurumu \\
\hline YA & Yusufeli ağzı \\
\hline YYA & Yalova ili yerli ağzı \\
\hline
\end{tabular}


Türkiye Türkçesinde 1930’lu Yıllardan Sonra Türetilen veya Canlandırılan Yeni Sözcüklerin Ağız Metinlerine Etkisinin Bir Örneklem Üzerinden Değerlendirilmesi

\section{EK 1 - İNCELENEN CALISMMLARDAKİ YENİ SÖZCÜKLERE DAİR BİLGILLER}

\begin{tabular}{|c|c|c|c|}
\hline $\begin{array}{l}\text { Yeni } \\
\text { Sözcük }\end{array}$ & $\begin{array}{l}\text { Eski Sözcük / } \\
\text { Anlam }\end{array}$ & Ağız Örneklemindeki Kullanımları & Notlar \\
\hline açı & $\begin{array}{l}\text { “Zâviye; görüş, } \\
\text { bakım, yön” }\end{array}$ & $\begin{array}{l}\text { "karar verdím kendi açımdan o zamanun şartlarna göre } \\
\text { yani" (AADKA - S.G. K/45). }\end{array}$ & \\
\hline adaylık & “Namzetlik” & $\begin{array}{c}\text { “undan sona bütün bölü şöför şiyine soKdulāadayliña” } \\
\text { (YYA - M.B. E/76) (2). }\end{array}$ & $\begin{array}{l}\text { Askerlikle ilgili olarak } \\
\text { kullanılmıştır. }\end{array}$ \\
\hline alan & $\begin{array}{l}\text { "Orman içindeki } \\
\text { açık yer" }\end{array}$ & $\begin{array}{c}\text { "böle biz alan deriz köyümüzün_otasında yüssek bi yé- } \\
\text { boşluk va" (YYA - S.B. K/80) } \\
\text { "bizum yaşam alanumuz çok çetin idi yavrum" (YA - P.D. } \\
\text { K/87). }\end{array}$ & $\begin{array}{l}\text { Not1: (<Eski Türkçe alang > } \\
\text { Eski Türkiye Türkçesi } \\
\text { alay/alan “orman içindeki açık } \\
\text { yer". Halk ağzında kullanılan } \\
\text { sözcük dil devrimiyle } \\
\text { canlandırılmıştır. (Bayar, } \\
\text { 2006:31) }\end{array}$ \\
\hline amaç & "Gāye, hedef" & $\begin{array}{l}\text { “yok, almak amaçl gideriz yāni, satmak için deyil” (LA - } \\
\text { G.A. K/52) } \\
\text { "amaci nedir biliyo musun" (AADKA - A.G. E/54) (2) } \\
\text { "öyle görme amacindan yani" (AADKA - S.G. K/45) (2) }\end{array}$ & $\begin{array}{c}\text { (<Farsça āmāc) Eskiden beri } \\
\text { kullanılan sözcük dil } \\
\text { devrimiyle canlandırılmıştır. } \\
\text { “Gāye, hedef”. } \\
\text { (Bayar, 2006:34) } \\
\text { Not2: Bu kullanımlardan üç } \\
\text { tanesi AADKA isimli } \\
\text { çalışmada derleyicinin söz } \\
\text { konusu kelimeyi kullanarak } \\
\text { sorduğu sorulara cevaben } \\
\text { söylenmiştir ve bu sorularda } \\
\text { kullanılan sözcüklerin tekrarı } \\
\text { niteliğindedir. }\end{array}$ \\
\hline an1 & “Hatıra" & $\begin{array}{c}\text { “askerlik anılarım isstá çok ey idi dedim ya” (YA-E.G. } \\
\text { E/84). }\end{array}$ & $\begin{array}{l}\text { Bu kullanım YA isimli } \\
\text { çalışmada sorulan “Var mı öyle } \\
\text { askerlik anıların?" sorusuna } \\
\text { cevaben söylenmiştir ve } \\
\text { soruda kullanılan sözcüğün } \\
\text { tekrarı niteliğindedir. }\end{array}$ \\
\hline anlam & “Mânâ" & $\begin{array}{l}\text { "köygöçüren deriz bu ekinin_içinde çıkar annamı da şu } \\
\text { çoḲ pis bi oTdur" (YYA-H.A.Ç. E/70). }\end{array}$ & \\
\hline anlayış & $\begin{array}{l}\text { "Telâkki, } \\
\text { zihniyet, } \\
\text { ferâset" }\end{array}$ & $\begin{array}{l}\text { “g̈àyınnam annayıșlı bi kadındı" (YYA - S.Y. K/77) (2) } \\
\text { "önden şindi böle annayıs mı vä̈ı" (YYA-E.E. K/73). }\end{array}$ & $\begin{array}{l}\text { Eskiden de kullanılan sözcük } \\
\text { dil devriminden sonra } \\
\text { canlandırılmıştır. (Bayar, } \\
\text { 2006:37) }\end{array}$ \\
\hline aracı & $\begin{array}{l}\text { "Vâsıta, } \\
\text { mutavassit, } \\
\text { şefaatçı" }\end{array}$ & $\begin{array}{c}\text { "o araciluk yaptu” (AADKA - B.A. K/79) (2) } \\
\text { "kendi kendine yoKa aracilan" (YYA-A.G. E/93) (2). }\end{array}$ & \\
\hline
\end{tabular}


Türkiye Türkçesinde 1930’lu Yıllardan Sonra Türetilen veya Canlandırılan Yeni Sözcüklerin Ağız Metinlerine Etkisinin Bir Örneklem Üzerinden Değerlendirilmesi

\begin{tabular}{|c|c|c|c|}
\hline araç & "Vâsıta, taşıt" & $\begin{array}{l}\text { “yok, biš ital veya birinci araç kullaniyus” (LA - S.G. } \\
\text { E/61). } \\
\text { "bi araç, araba na kada benzin yake, onlarun şeylarini } \\
\text { kilometrelarini ben ayarlardím "(YA - E.G. E/84). }\end{array}$ & $\begin{array}{l}\text { YA'daki kullanımı askerlikle } \\
\text { ilgilidir. }\end{array}$ \\
\hline astsubay & $\begin{array}{l}\text { “Orduya özel } \\
\text { bir yasa ile } \\
\text { onbaşı, çavuş ya } \\
\text { da başçavuş } \\
\text { olarak katılan } \\
\text { asker" }\end{array}$ & "benum askerluĝum, ben $\frac{\text { assubayidim" }}{(2) .}(Y A-E . G$. E/84) & $\begin{array}{l}\text { Askerlikle ilgili bir terim } \\
\text { olarak kullanılmıştır. }\end{array}$ \\
\hline aşama & $\begin{array}{l}\text { "Mertebe, } \\
\text { derece, rütbe, } \\
\text { merhale" }\end{array}$ & "așama oncesi ağaçta silkeliyosun" (AADKA - A.G. E/54). & $\begin{array}{l}\text { Bu kullanım AADKA isimli } \\
\text { çalışmada derleyicinin } \\
\text { sorduğu "Nasıl ama o aşama } \\
\text { nasıl?" sorusuna cevaben } \\
\text { söylenmiştir ve soruda } \\
\text { kullanılan sözcüğün tekrarı } \\
\quad \text { niteliğindedir. }\end{array}$ \\
\hline atasözü & “Darb-1 mesel” & $\begin{array}{c}\text { "iyilik yap kötülüK bul diye laf var bunnar meşur laflar } \\
\text { bunnar atasösleri" (YYA-O.G. E/67). }\end{array}$ & \\
\hline ayrım & $\begin{array}{l}\text { "Tefrik, fark, yol } \\
\text { kavşağı, bölüm, } \\
\text { bölük, parça" }\end{array}$ & 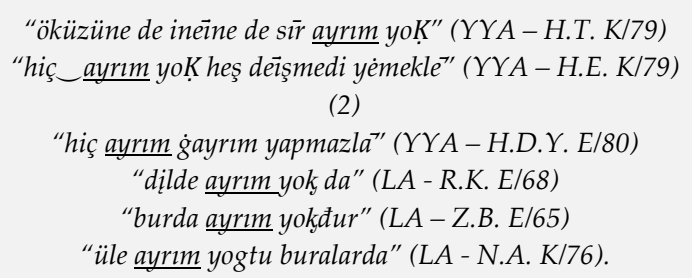 & $\begin{array}{l}\text { Sik kullanılan "ayrım gayrım" } \\
\text { ikilemesi dikkat çekicidir. }\end{array}$ \\
\hline bakan & "Nâzır" & “ismet İnönü başbaǩān" (YA - R.K. E/94). & $\begin{array}{l}\text { Başbakan yapısının içinde } \\
\text { kullanılmıştır. }\end{array}$ \\
\hline bakanlık & "Nezâret" & "o tarım baǩanlìğíndan" (LA - R.K. E/68) & $\begin{array}{l}\text { Bir devlet kuruluşu isminin } \\
\text { içinde kullanılmıştır. }\end{array}$ \\
\hline başarı & "Muvaffakiyet" & $\begin{array}{c}\text { "iyi günlar yaşamayi nasib eda, bașarilar dilarım" (YA- } \\
\text { R.D. E/67). }\end{array}$ & \\
\hline başkan & “Reis, ser" & 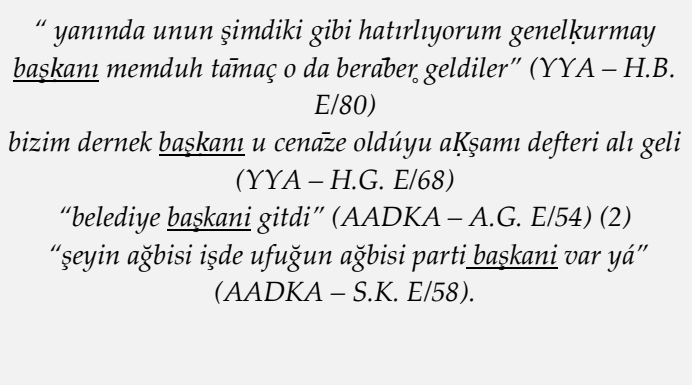 & $\begin{array}{l}\text { Not1: Eskiden de var olan ve } \\
\text { zaman içinde kullanımdan } \\
\text { düşmüş bir sözcük iken Dil } \\
\text { Devrimiyle birlikte } \\
\text { canlandırılmıştır. (Bayar, } \\
\text { 2006:52). } \\
\text { Not2: Örnekler resmî unvan } \\
\text { belirten ifadelerde } \\
\text { kullanılmıştır. }\end{array}$ \\
\hline
\end{tabular}


Türkiye Türkçesinde 1930’lu Yıllardan Sonra Türetilen veya Canlandırılan Yeni Sözcüklerin Ağız Metinlerine Etkisinin Bir Örneklem Üzerinden Değerlendirilmesi

\begin{tabular}{|c|c|c|c|}
\hline bayan & $\begin{array}{l}\text { "Kadınların } \\
\text { adları yerine } \\
\text { kullanılır, } \\
\text { hanım" }\end{array}$ & 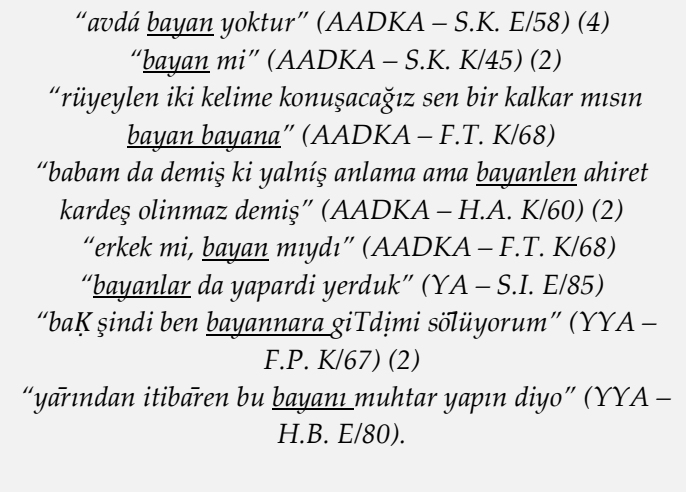 & $\begin{array}{l}\text { AADKA'da yer alan S.K.'nin } \\
\text { ve H.A.'nın kullandığı } \\
\text { örnekler derlemecinin sorduğu } \\
\text { “bayan” sözcüğünü içeren } \\
\text { sorulara cevaben söylenmiştir } \\
\text { ve sorularda kullanılan } \\
\text { sözcüklerin tekrarı } \\
\text { niteliğindedir. YYA'da yer } \\
\text { alan H.B.'nin kullanımında ise } \\
\text { sözcüğün kaynak kişi } \\
\text { tarafından bir başkasının } \\
\text { cümlesi iletilirken kullanıldı̆̆ } 1 \\
\text { belirtilmelidir. }\end{array}$ \\
\hline belgele- & "Tevsik etmek" & "tabi belgeleniyo" (AADKA - S.B. E/54). & \\
\hline bencil & $\begin{array}{l}\text { "Hodkâm, } \\
\text { Egoist" }\end{array}$ & "çok benculdürler" (AADKA - F.T. K/68). & \\
\hline biçim & "Şekil" & $\begin{array}{l}\text { "böle çoÇūm böle çiçeK aynı işde doḳunuyonuz yāaynı } \\
\text { onun biçiminde çiçein" (YYA-H.D. K/84). }\end{array}$ & $\begin{array}{c}\text { Eskiden beri kullanılan sözcük } \\
\text { "şekil" karşılığyyla yeni kelime } \\
\text { olarak kullanılmıştır } \\
\text { (Bayar, 2006:58) }\end{array}$ \\
\hline bilgisayar & $\begin{array}{l}\text { "Kompütür, } \\
\text { elektronik } \\
\text { beyin" }\end{array}$ & $\begin{array}{c}\text { "az_okudum_ama senden fazla bilirim bilgisayar gibi" } \\
(Y Y A-M . Y . K / 86) .\end{array}$ & Teknolojik alet adıdır. \\
\hline bitki & "Nebat" & $\begin{array}{l}\text { "ne bileyim yani bitki çeşidi" ( AADKA - S.K. E/58) } \\
\text { "bu dere kenarindá, hiç bişe bitki" (AADKA - Z.T. E/72). }\end{array}$ & $\begin{array}{l}\text { Halk ağzında var olan kelime } \\
\text { "nebat" karşılığında } \\
\text { canlandırılmıştır } \\
\text { (Bayar, 2006:63). } \\
\text { Bu kullanım AADKA isimli } \\
\text { çalışmada derleyicinin } \\
\text { sorduğu "Peki bu derelerin } \\
\text { kenarlarında ne gibi bitkiler } \\
\text { yetişiyor?" sorusuna cevaben } \\
\text { söylenmiştir ve soruda } \\
\text { kullanılan sözcüğün tekrarı } \\
\text { niteliğindedir. }\end{array}$ \\
\hline bölge & "Mıntıka" & $\begin{array}{c}\text { "bizum bu bolgede kafkas arisi meşhur" (AADKA - S.K. } \\
\text { E/58) (2) } \\
\text { "biz burda şeydeyiz mahrumiyet bölgesinde" (AADKA- } \\
\text { N.A. K/63) } \\
\text { "dülgerli dedığımız zaman tabi çok uzak bölge" (AADKA- } \\
\text { S.B. E/54) (2) } \\
\text { "yalova tarafinda o bölgede" (YA-Z.A. E/73) (2) } \\
\text { "bizim bu ege bölgésinde ege, sāỷil boylarında işimiz } \\
\text { çok, olurdu" (LA - S.G. E/61). }\end{array}$ & $\begin{array}{l}\text { Not1: Eskiden de kullanılmış, } \\
\text { zaman içinde kullanımdan } \\
\text { düşmüşken canlandırılmış bir } \\
\text { sözcüktür. } \\
\text { (Bayar, 2006:64) } \\
\text { Not2: LA'da yer alan S.G.'nin } \\
\text { kullanımı bir özel ismin } \\
\text { parçasıdır. }\end{array}$ \\
\hline
\end{tabular}


Türkiye Türkçesinde 1930'lu Yıllardan Sonra Türetilen veya Canlandırılan Yeni Sözcüklerin Ağız Metinlerine Etkisinin Bir Örneklem Üzerinden Değerlendirilmesi

\begin{tabular}{|c|c|c|c|}
\hline buzdolabı & $\begin{array}{c}\text { “Yiyecek ve } \\
\text { içecekleri soğuk } \\
\text { tutup } \\
\text { bozulmasını } \\
\text { önlemek için } \\
\text { kullanılan } \\
\text { dolap" }\end{array}$ & $\begin{array}{c}\text { "buzdolabını__üstüne dō̄u baK ġızım" (YYA - F.P. } \\
\text { K/67) } \\
\text { “yandaki odalar yan oda, o buzdolabiolan" (AADKA- } \\
\text { H.G. K/82) (2) }\end{array}$ & Teknolojik alet adıdır. \\
\hline çabala- & $\begin{array}{l}\text { "Cehdetmek, } \\
\text { gayret etmek" }\end{array}$ & 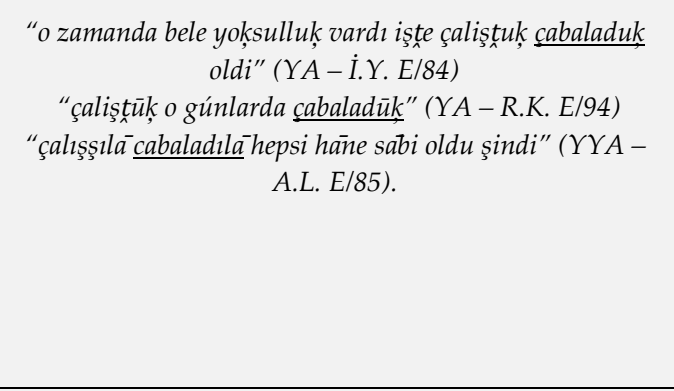 & $\begin{array}{c}\text { Not } 1 \text { : Eskiden de kullanılan } \\
\text { sözcük, ölçünlü Türkçede } \\
\text { canlandırılmıştır } \\
\text { (Bayar, 2006:71) } \\
\text { Not } 2 \text { : Sözcük incelenen } \\
\text { ağızlarda yer alan tüm } \\
\text { örneklerde "çalışmak } \\
\text { çabalamak" ikilemesi } \\
\text { içerisinde kullanılmıştır. }\end{array}$ \\
\hline çoğunluk & “Ekseriyet” & $\begin{array}{c}\text { "tabi ama çoğunluktan ise azalma oldu şimdi" (AADKA- } \\
\text { S.G. K/45). }\end{array}$ & \\
\hline çoğunlukla & $\begin{array}{l}\text { “Ekseriyetle, } \\
\text { ekseriya, çoğu } \\
\text { zaman” }\end{array}$ & $\begin{array}{c}\text { “coğunluklá çaşída kalíyoríz"(AADKA - Ş.Ö. K/72) (2) } \\
\text { "bi da istíríç olur ufak tefek yăni coğunluklen" (AADKA- } \\
\text { Z.T. E/72). }\end{array}$ & \\
\hline dağıtım & “Tevzi” & $\begin{array}{c}\text { "taĝ̣ıtım oldi úçak savar bölügündayduk," (YYA-A.T. } \\
\text { E/78). }\end{array}$ & $\begin{array}{l}\text { Askerlikle ilgili bir terim } \\
\text { olarak kullanılmıştır. }\end{array}$ \\
\hline değişim & $\begin{array}{l}\text { “Tahavvül, bir } \\
\text { süreç içindeki } \\
\text { değişikliklerin } \\
\text { tümü" }\end{array}$ & "hava değişimi oldi" (AADKA - B.A. K/79). & $\begin{array}{l}\text { Tıp ya da askerlikle ilgili } \\
\text { olarak kullanılabilen “hava } \\
\text { değişimi” yapısının içinde yer } \\
\text { almıştır. }\end{array}$ \\
\hline dene- & $\begin{array}{l}\text { "Tecrübe etmek, } \\
\text { teşebbüs etmek" }\end{array}$ & "ben işiTdim ama denediyimiz yoK" (YYA - H.Y. E/84). & $\begin{array}{l}\text { Eskiden de kullanılan sözcük } \\
\text { “tecrübe etmek" karşılığında } \\
\text { teklif edilmiştir. } \\
\text { (Bayar, 2006:85-86) }\end{array}$ \\
\hline dernek & “Cemiyet" & $\begin{array}{c}\text { "bizim dernek başkanı u cenāze oldúyu aK̦şamı defteri alı } \\
\text { geli" (YYA-H.G. E/68). }\end{array}$ & $\begin{array}{l}\text { Eskiden de kullanılan sözcük } \\
\text { "cemiyet" karşılığında } \\
\text { canlandırılmıştır. } \\
\text { (Bayar, 2006:88-89) }\end{array}$ \\
\hline deyim & “Tâbir" & "bi deyim vardi" (AADKA - A.B. K/43). & \\
\hline
\end{tabular}


Türkiye Türkçesinde 1930’lu Yıllardan Sonra Türetilen veya Canlandırılan Yeni Sözcüklerin Ağız Metinlerine Etkisinin Bir Örneklem Üzerinden Değerlendirilmesi

\begin{tabular}{|c|c|c|c|}
\hline doğal & “Tabii" & 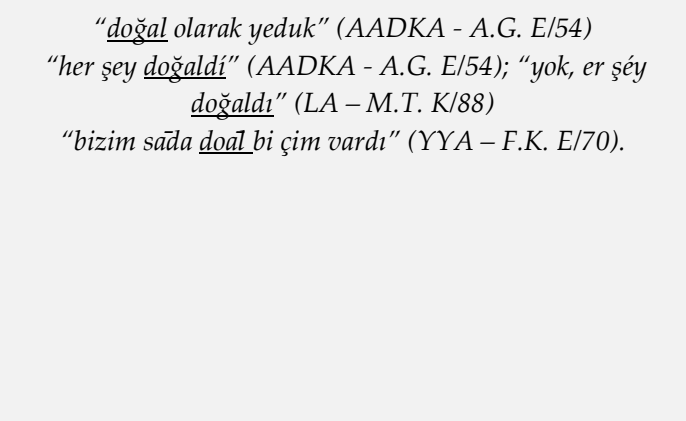 & $\begin{array}{l}\text { LA kaynak kişilerinden M.T. } \\
\text { bu sözcüğün geçtiği cümleyi } \\
\text { derleyicinin sorduğu “E her } \\
\text { şeyi doğal yapıyormuşsunuz } \\
\text { zaten. Kendiniz büyütüyorsunuz, } \\
\text { kendiniz yiyorsunuz." } \\
\text { yorumuna cevaben kurmuştur } \\
\text { ve bu kullanımın yorumda } \\
\text { kullanılan sözcüğün tekrarı } \\
\text { niteliğinde olduğu } \\
\text { söylenebilir. }\end{array}$ \\
\hline doğu & "Şark" & $\begin{array}{c}\text { "baḲ iki sene askerliK yapdım men doüda yapdım" (YYA- } \\
\text { H.Y. E/84). }\end{array}$ & $\begin{array}{l}\text { Not } 1 \text { : Eskiden de kullanılan } \\
\text { kelime "şark" karşılığında } \\
\text { canlandırılmıştır. } \\
\text { (Bayar, 2006:97) } \\
\text { Not 2: } \\
\begin{aligned} \text { Askerlikle ilgili olarak } \\
\text { kullanılmıştır. }\end{aligned}\end{array}$ \\
\hline doruk & "Şahika, zirve" & "dādorunda kilitli sandiḲ" " (YYA- E.P. K/47). & $\begin{array}{l}\text { Not1: Eskiden de kullanılan } \\
\text { kelime “şahika” karşılığında } \\
\text { canlandırılmıştır } \\
\text { (Bayar, 2006:97). } \\
\text { Not2: Kalıp yapı olan bir } \\
\text { bilmecenin içinde } \\
\text { kullanılmıştır. }\end{array}$ \\
\hline dönem & "Devre" & 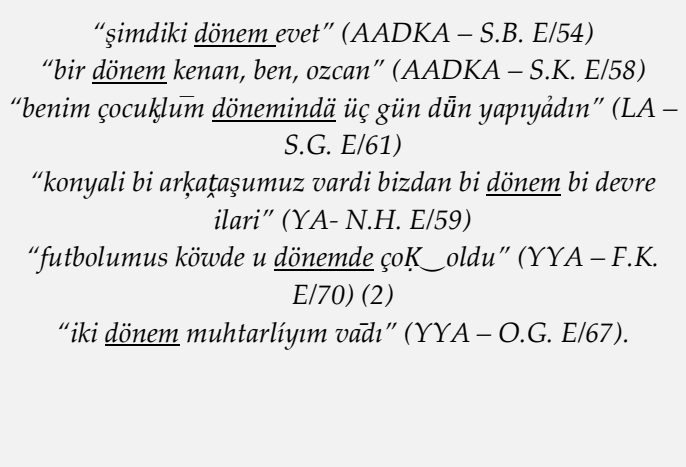 & $\begin{array}{l}\text { YA kaynak kişilerinden } \\
\text { N.H.'nin kullanımı askerlikle } \\
\text { ilgilidir ve aynı anlama gelen } \\
\text { “devre" ve "dönem" } \\
\text { sözcüklerini birlikte } \\
\text { kullanması dikkat çekicidir. } \\
\text { Dile yeni alınan kelimenin aynı } \\
\text { cümlede dilde önceden yer } \\
\text { alan eş anlamlısıyla birlikte } \\
\text { kullanılması, yeni sözcüklerin } \\
\text { dile girme aşamalarında } \\
\text { sıklıkla görülür. }\end{array}$ \\
\hline dönüş & "Avdet, rücu" & $\begin{array}{c}\text { "iki senede dönüs yaPdım ben_ordan" (YYA-O.G. E/82) } \\
\text { "dönüșde geldi baḲdı evine" (YYA-A.A. E/68). }\end{array}$ & $\begin{array}{l}\text { Eskiden de kullanılan sözcük } \\
\text { canlandırılmıştır } \\
\text { (Bayar, 2006:100). }\end{array}$ \\
\hline
\end{tabular}


Türkiye Türkçesinde 1930’lu Yıllardan Sonra Türetilen veya Canlandırılan Yeni Sözcüklerin Ağız Metinlerine Etkisinin Bir Örneklem Üzerinden Değerlendirilmesi

\begin{tabular}{|c|c|c|c|}
\hline durum & $\begin{array}{l}\text { "Vaziyet, hal, } \\
\text { mevki, keyfiyet" }\end{array}$ & 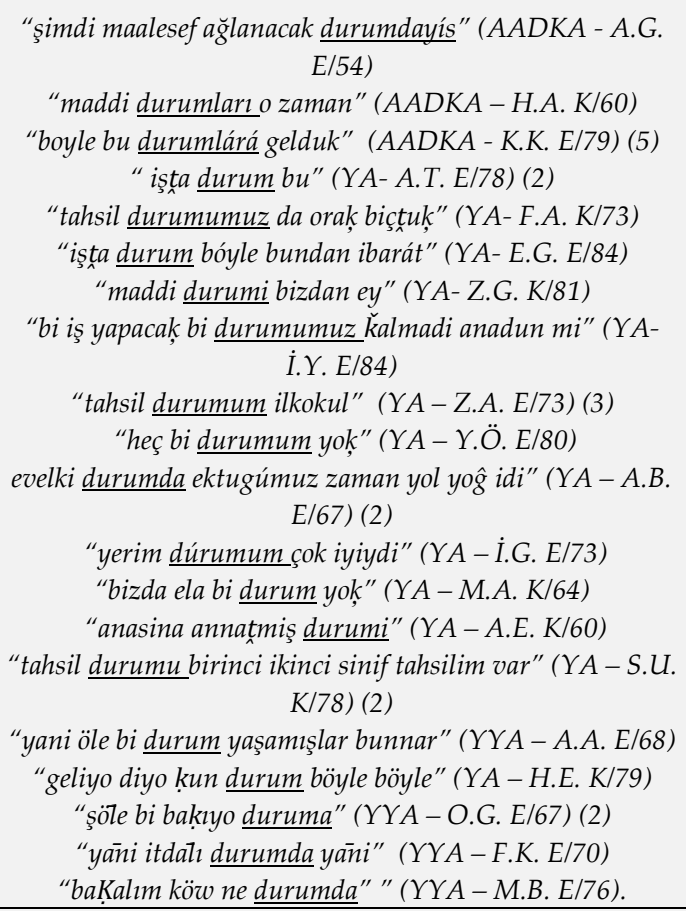 & $\begin{array}{l}\text { YY'de F.A. , Z.A., Y.Ö., A.B., } \\
\text { S.U. isimli kaynak kişilerin } \\
\text { kullandığı söz konusu } \\
\text { kelimelerin geçtiği } \\
\text { cümlelerdeki kullanımlar, } \\
\text { derleyicinin sorduğu “Tahsil } \\
\text { durumunuz nedir?” sorusuna } \\
\text { cevaben söylenmiştir ve } \\
\text { soruda kullanılan sözcüğün } \\
\text { tekrarı niteliğindedir. }\end{array}$ \\
\hline eğitim & $\begin{array}{l}\text { "Terbiye, } \\
\text { eğitmek işi" }\end{array}$ & $\begin{array}{c}\text { "aķşama ǩadar eğitim" (YA-R.D. E/67) (3) } \\
\text { "hem de gece egitimi varidi bizim devrimizde" (YA-Y.Ö. } \\
\text { E/80) (2) } \\
\text { "eşim da milli eğitimdan emekli oldi" (YA-M.A. K/64) } \\
\text { "êytim ilkokul yavrum" (YYA-F.P. K/67) } \\
\text { "bornovada kırḲ beş gün bi şey_ịtimi gördük piyäde" } \\
\text { (YYA-M.B. E/76). }\end{array}$ & $\begin{array}{l}\text { YA kaynak kişilerinden R.D. } \\
\text { ve YYA kaynak kişilerinden } \\
\text { M.B.'nin kullanımları } \\
\text { askerlikle ilgilidir. YA kaynak } \\
\text { kişilerinden M.A.'nın } \\
\text { kullanımı özel bir adın içinde } \\
\text { geçen ifade iken YYA kaynak } \\
\text { kişilerinden F.P.'nin kullanımı } \\
\text { derleyicinin “eğitim durumunuz } \\
\text { nedir?" sorusuna cevaben } \\
\text { verilmiştir ve soruda } \\
\text { kullanılan sözcüğün tekrarı } \\
\text { niteliğindedir. YA kaynak } \\
\text { kişilerinden Y.Ö. ise tahsil } \\
\text { durumuyla alakalı bilgi } \\
\text { verirken bahsi geçen sözcü̆ğü } \\
\text { kullanmıştır. }\end{array}$ \\
\hline eğitmen & $\begin{array}{l}\text { "Mürebbi, } \\
\text { öğretmen" }\end{array}$ & $\begin{array}{c}\text { "o zaman ögretmen yog gidi egitmen idi egitmen" (YA- } \\
\text { Y.Ö. E/80) (2). }\end{array}$ & $\begin{array}{l}\text { Eğitimle alakalı resmî bir } \\
\text { meslek adı belirtilirken } \\
\text { kullanılmıştır. }\end{array}$ \\
\hline ekim (ay) & “Teşrînievvel” & $\begin{array}{l}\text { "ekim kasım ayindá" (AADKA-S.K. E/58) (2) } \\
\text { "hangi ay diyim yani ekim" (AADKA-S.G. K/45) (5) } \\
\text { "efendıma söyleyeyim } \frac{\text { ekim ayindaydi" (AADKA - A.G. }}{E / 54)(3)} \\
\text { "bizim da ekim ayında üzum oluyo" (AADKA - H.A. } \\
\text { K/60) } \\
\text { "ondan sora eylül, eylül ekimde" (AADKA-S.K. E/58) (2) } \\
\text { "eylül, ekimda yetişiyo zaten misir" (AADKA - A.B. } \\
\text { K/43) }\end{array}$ & \\
\hline
\end{tabular}


Türkiye Türkçesinde 1930’lu Yıllardan Sonra Türetilen veya Canlandırılan Yeni Sözcüklerin Ağız Metinlerine Etkisinin Bir Örneklem Üzerinden Değerlendirilmesi

\begin{tabular}{|c|c|c|c|}
\hline emek & “Sa'y" & "emek o altı yüs tane" (AADKA - S.G. K/45) & $\begin{array}{l}\text { Eskiden beri kullanılan sözcük } \\
\text { farklı bir anlamda } \\
\text { canlandırılmıştır. } \\
\text { (Bayar, 2006:112-113). }\end{array}$ \\
\hline emekli & $\begin{array}{l}\text { "Mütekâit, } \\
\text { tekaüt" }\end{array}$ & 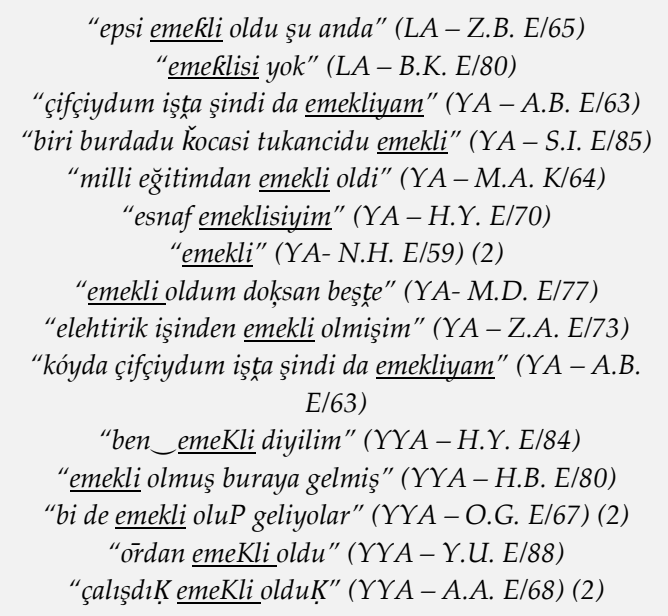 & $\begin{array}{l}\text { Not1: YYA kaynak kişilerinden } \\
\text { H.Y. ve YA kaynak } \\
\text { kişilerinden N.H.'nin } \\
\text { kullanımlarından birer tanesi } \\
\text { derleyicilerin sorduğu } \\
\text { “Nereden emekli oldunuz?” } \\
\text { sorusuna cevaben söylenmiştir } \\
\text { ve soruda kullanılan sözcüğün } \\
\text { tekrarı niteliğindedir. } \\
\text { Not2: Bu sözcüklerden tümü } \\
\text { kaynak kişilerin meslekleriyle } \\
\text { ilgili bir terim olarak } \\
\text { kullanılmıştır. }\end{array}$ \\
\hline engel & $\begin{array}{c}\text { "Mâni, müşkil, } \\
\text { mahzur" }\end{array}$ & "ne yapabiliriz engel olamíyoruz" (AADKA - G.D. E/67). & $\begin{array}{l}\text { Aslı Farsçadır, eskiden "rakip" } \\
\text { anlamında kullanılmış ve daha } \\
\text { sonra "mâni" karşılığından } \\
\text { canlandırılmıştır. } \\
\text { (Bayar, 2006:113-114). }\end{array}$ \\
\hline eşit & "Müsâvi" & 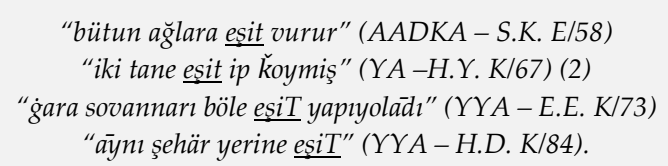 & \\
\hline etkilen- & $\begin{array}{l}\text { "Müteessir } \\
\text { olmak" }\end{array}$ & $\begin{array}{c}\text { "etkilenmis gülüm" (YYA-R.T. E/80) } \\
\text { "eeh etkilenme biz bişe anlayamaduk ta yani" (AADKA- } \\
\text { K.K. E/79). }\end{array}$ & $\begin{array}{l}\text { Bu kullanımlar AADKA ve YA } \\
\text { isimli çalışmada derleyicilerin } \\
\text { sorduğu "Yalova Katliamı } \\
\text { döneminde bu köy de etkilenmiş } \\
\text { mi?" ve "Etkilenme olayı } \\
\text { nasıldı?" sorularına cevaben } \\
\text { söylenmiştir ve sorularda } \\
\text { kullanılan sözcüklerin tekrarı } \\
\text { niteliğindedir. }\end{array}$ \\
\hline geçerli & $\begin{array}{l}\text { “Yürürlükte } \\
\text { olan, sürümü } \\
\text { olan” }\end{array}$ & $\begin{array}{c}\text { "baK_ o zamanın zamānında bi para gecerlidi" (YYA- } \\
\text { A.G. E/93). }\end{array}$ & \\
\hline
\end{tabular}


Türkiye Türkçesinde 1930’lu Yıllardan Sonra Türetilen veya Canlandırılan Yeni Sözcüklerin Ağız Metinlerine Etkisinin Bir Örneklem Üzerinden Değerlendirilmesi

\begin{tabular}{|c|c|c|c|}
\hline geçim & $\begin{array}{l}\text { "Maişet, } \\
\text { imtizaç" }\end{array}$ & 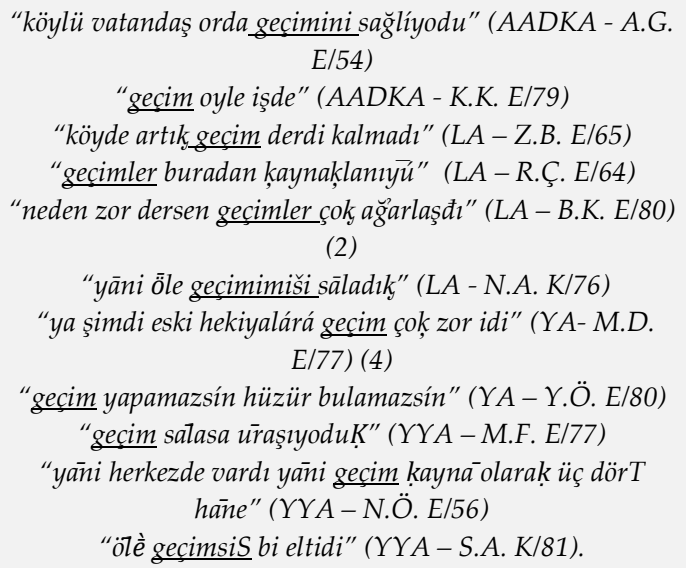 & $\begin{array}{l}\text { Not1: Eskiden de kullanılan } \\
\text { sözcük “maişet” karşılığında } \\
\text { canlandırılmıştır. } \\
\text { (Bayar, 2006:129). } \\
\text { Not2: AADKA kaynak } \\
\text { kişilerinden K.K. ve YYA } \\
\text { kaynak kişilerinden N.Ö.'nün } \\
\text { kullanımları derleyicilerin } \\
\text { sorduğu “Peki nasıl geçiminizi } \\
\text { sağladınız?" ve “Köyün geçim } \\
\text { kaynağı nedir?" sorularına } \\
\text { cevaben söylenmiştir ve } \\
\text { sorularda kullanılan sözcüğ̈un } \\
\text { tekrarı niteliğindedir. }\end{array}$ \\
\hline geçmiş & "Mâzi" & $\begin{array}{c}\text { “bén ikaye diyil, ben geçmișimi söylüyorum sadece" (LA - } \\
\text { S.G. E/61). }\end{array}$ & $\begin{array}{l}\text { Eskiden de kullanılan sözcük } \\
\text { "mâzi” karşılığında } \\
\text { canlandırılmıştır. } \\
\text { (Bayar, 2006:130). }\end{array}$ \\
\hline gelecek & "İstikbal" & $\begin{array}{c}\text { "gelijekte mi?"(LA - S.G. E/61) (2) } \\
\text { “sen şini śok gǚšl bi soru sordun bize, gelicekđen bi şey } \\
\text { sordun da" (LA-R.Ç. E/64). }\end{array}$ & $\begin{array}{l}\text { Not1: Eskiden de kullanılan } \\
\text { sözcük “istikbal” karşıllğında } \\
\text { canlandırılmıştır. } \\
\text { (Bayar, 2006:130). } \\
\text { Not2: LA kaynak kişilerinden } \\
\text { R.Ç.'nin kullanımı derleyicinin } \\
\text { sorduğu “Gelecekle ilgili bir } \\
\text { kayginız var mı?” sorusuna } \\
\text { cevaben söylenmiştir ve } \\
\text { soruda kullanılan sözcüğün } \\
\text { tekrarı niteliğindedir. }\end{array}$ \\
\hline gelenek & "Anane" & $\begin{array}{l}\text { "bizım memleket geleneklerínden en değerli bir úrúndúr" } \\
\text { (AADKA-S.B. E/54) (2) } \\
\text { "yoK öte fazla gelenek yoḲ" (YYA-F.G. K/70). }\end{array}$ & $\begin{array}{l}\text { YYA kaynak kişilerinden } \\
\text { F.G.'nin kullanımı derleyicinin } \\
\text { sorduğu “Bu köye özgü bir } \\
\text { geleneğiniz var mı aklınıza } \\
\text { gelen?” sorusuna cevaben } \\
\text { söylenmiştir ve soruda } \\
\text { kullanılan sözcüğün tekrarı } \\
\text { niteliğindedir. }\end{array}$ \\
\hline geleneksel & “Ananevi” & $\begin{array}{c}\text { "ondan sora geleneksel şeyler var" (AADKA-A.B. K/43) } \\
\text { "atmaca bi geneleksel evvelden beri bi geneleksel bi şey gibi } \\
\text { sanat gibi ġalmiş" (AADKA - Ş.Ö. K/72) } \\
\text { "en önemli özelliği, geleneksel tohum yönteminle, tarım } \\
\text { yapıyo" (LA-G.K. E/49). }\end{array}$ & \\
\hline
\end{tabular}


Türkiye Türkçesinde 1930’lu Yıllardan Sonra Türetilen veya Canlandırılan Yeni Sözcüklerin Ağız Metinlerine Etkisinin Bir Örneklem Üzerinden Değerlendirilmesi

\begin{tabular}{|c|c|c|c|}
\hline gelir & "İrat, vâridat" & $\begin{array}{l}\text { "gelirini fazla miktardaki insanlar çaylán sağlamaktadur" } \\
\text { (AADKA - Z.T. E/72) } \\
\text { "bèyazıt Çamisinin u geliri bizim bu köwün şeysi" (YYA- } \\
\text { G.K. K/70) (2) } \\
\text { "ama gelirimis balıKçılıK" (YYA - G.G. K/67). }\end{array}$ & \\
\hline geliş- & "İnkişâf etmek" & "teknolojinin kendilinden geliștinden" (LA - S.G. E/61). & $\begin{array}{l}\text { Eskiden de kullanılan sözcük } \\
\text { "inkişâf etmek" karşılığında } \\
\text { canlandırılmıştır. } \\
\text { (Bayar, 2006:131). }\end{array}$ \\
\hline genel & "Umûmi" & 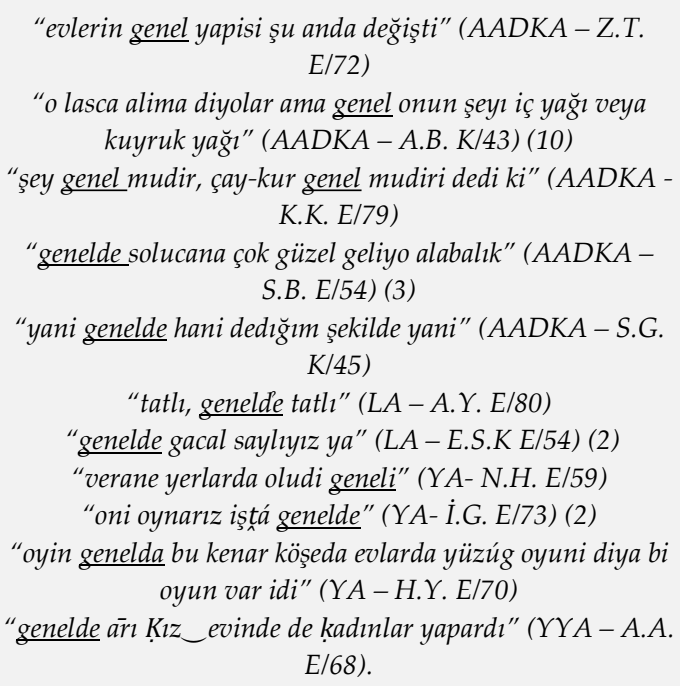 & \\
\hline genellikle & “Umumiyetle” & $\begin{array}{l}\text { "genellikle idare ediyo yani"(AADKA - A.G. E/54) (2) } \\
\text { "génellikle pilav olur bizim mévlidlerde" (LA - G.Ö. K/52) } \\
\text { "genellikla pazertasi veya perşembe gecalari gidardilar"(YA } \\
- \text { A.B. E/67) }\end{array}$ & \\
\hline $\begin{array}{l}\text { genelkurma } \\
\mathrm{y}\end{array}$ & $\begin{array}{l}\text { “Erkân-1 } \\
\text { Harbiye-i } \\
\text { Umûmiye }\end{array}$ & $\begin{array}{c}\text { "genelkurmay başkanı memduh tāmaço da beraber。 } \\
\text { geldiler" (YYA-H.B. E/80) }\end{array}$ & $\begin{array}{l}\text { Askerlikle ilgili bir terim } \\
\text { olarak kullanılmıştır. }\end{array}$ \\
\hline gerçek & $\begin{array}{l}\text { "Hakikat, } \\
\text { realite" }\end{array}$ & $\begin{array}{c}\text { "daKım fenerbaççe hemen hemen millị takım gerçek } \\
\text { fenerbaççe" (YYA-F.K. E/70) } \\
\text { "gerçek diyorum"(AADKA - A.G. E/54) (3) }\end{array}$ & $\begin{array}{l}\text { Eskiden de kullanılan sözcük } \\
\text { 'hakikat' karşılığında } \\
\text { canlandırılmıştır. (Bayar, } \\
\text { 2006:133). }\end{array}$ \\
\hline gerçekten & "Filhakîka, sâhi" & $\begin{array}{r}\text { "hoş gerçekten atti deyincá da hoş"( } A A D K A-A . B . \text { K/43) } \\
\text { "gerçekten dünyaca ünlü bi balık yani" (AADKA-S.B. } \\
\text { E/54) (3) } \\
\text { "gerçekten burada tarím olarak zirai çay üreticisiyiz" } \\
\text { (AADKA - Z.T. E/72) (2) } \\
\text { "gerçekten gidemedim" (AADKA - A.G. E/54) } \\
\text { "tükûr la gerçektan dedi" (YA- N.H. E/59). }\end{array}$ & $\begin{array}{l}\text { YA kaynak kişilerinden N.H. } \\
\text { tercih ettiği örneği başka } \\
\text { birinin söylediği bir sözü } \\
\text { aktardığı sırada kullanmıştır. }\end{array}$ \\
\hline
\end{tabular}


Türkiye Türkçesinde 1930’lu Yıllardan Sonra Türetilen veya Canlandırılan Yeni Sözcüklerin Ağız Metinlerine Etkisinin Bir Örneklem Üzerinden Değerlendirilmesi

\begin{tabular}{|c|c|c|c|}
\hline gerilim & $\begin{array}{l}\text { "Tevettür, } \\
\text { tansiyon" }\end{array}$ & $\begin{array}{l}\text { "afiyon'la şey arasinda yüksek gerilim götürduk, elehtirik" } \\
\text { (YA-M.D. E/77) }\end{array}$ & $\begin{array}{l}\text { YA kaynak kişilerinden M.D. } \\
\text { sözcügü mesleğiyle ilgili bir } \\
\text { terim olarak kullanmıştır. }\end{array}$ \\
\hline giriş & "Methal" & $\begin{array}{l}\text { "bizum yok mahallenun girișinde bağudit var ya kayaluk } \\
\text { varya" (AADKA - S.K. E/58) } \\
\text { bizim bu girișde büyük_aşlarımı vǟı (YYA-H.G. E/68) }\end{array}$ & $\begin{array}{l}\text { Eskiden de kullanılan sözcük } \\
\text { 'methal' karşıllı̆ında } \\
\text { canlandırılmıştır. (Bayar, } \\
\text { 2006:133). }\end{array}$ \\
\hline göçmen & "Muhacir" & $\begin{array}{l}\text { "onlar đā başka göçmen" (LA - R.Ç. E/64) (2) } \\
\text { "élli birde gelen göçmenlerimiz var" (LA S.T. E/86) (2) } \\
\text { "benim ānne, anne tarafim göçmen" (LA - G.Ö. K/52) } \\
\text { "göçmenlérden biyendim" (LA - B.K. E/80) } \\
\text { "göçmen" (LA - A.K. K/73) } \\
\text { "drama gősçmeni" (LA - M.T. K/88) }\end{array}$ & $\begin{array}{l}\text { LA kaynak kişilerinden G.Ö. } \\
\text { ve A.K.'nin kullandığı örnekler } \\
\text { derlemecinin sorduğu } \\
\text { "göçmen" sözcügüüü içeren } \\
\text { soruya cevaben söylenmiştir } \\
\text { ve soruda kullanılan sözcüğün } \\
\text { tekrarı niteliğindedir. }\end{array}$ \\
\hline görenek & 'ÂAdet' & $\begin{array}{c}\text { "koyúmuzdan eski góreneklardan mi?" (YA- R.K. E/94) } \\
\text { "ne bilem hirdellezin u şeysi göreneyi" (YYA - S.Y. K/77) } \\
\text { (2). }\end{array}$ & $\begin{array}{c}\text { Not1: Eskiden de kullanılan } \\
\text { sözcük ‘Âdet' karşıllğında } \\
\text { canlandırılmıştır. (Bayar, } \\
\text { 2006:133). } \\
\text { Not2: YA kaynak kişilerinden } \\
\text { R.K.'nin kullandığı örnek } \\
\text { derlemecinin sorduğu } \\
\text { “Amcacığım köylerinizdeki } \\
\text { gelenek göreneklerden biraz } \\
\text { bahseder misiniz?” sorusuna } \\
\text { cevaben söylenmiştir ve } \\
\text { soruda kullanılan sözcüğün } \\
\text { tekrarı niteliğindedir. }\end{array}$ \\
\hline görev & "Vazife" & 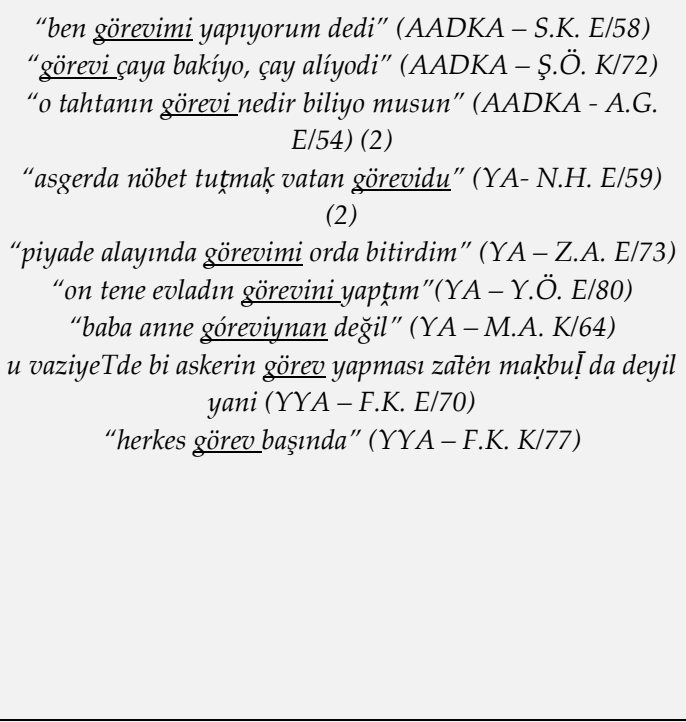 & $\begin{array}{l}\text { Not1: AADKA kaynak } \\
\text { kişilerinden Ş.Ö.'nün } \\
\text { kullandığı örnek derlemecinin } \\
\text { sorduğu "görev" sözcügünü } \\
\text { içeren soruya cevaben } \\
\text { söylenmiştir ve soruda } \\
\text { kullanılan sözcüğün tekrarı } \\
\text { niteliğindedir. } \\
\text { Not2: AADKA kaynak } \\
\text { kişilerinden S.K. tercih ettiği } \\
\text { örneği başka birinin söylediği } \\
\text { bir sözü aktardığı sırada } \\
\text { kullanmıştır. } \\
\text { Not3: YA kaynak kişilerinden } \\
\text { N.H. ve Z.A. ile YYA kaynak } \\
\text { kişilerinden F.K.'nin } \\
\text { kullanımları askerlikle ilgilidir. }\end{array}$ \\
\hline görünüm & "Manzara" & “o gorunumler güzeldi” (AADKA - S.G. K/45). & \\
\hline
\end{tabular}


Türkiye Türkçesinde 1930’lu Yıllardan Sonra Türetilen veya Canlandırılan Yeni Sözcüklerin Ağız Metinlerine Etkisinin Bir Örneklem Üzerinden Değerlendirilmesi

\begin{tabular}{|c|c|c|c|}
\hline görüş̧ & “Fikir" & $\begin{array}{l}\text { "genĉler gendi görüşlerine göre o parayi alur harcardiler" } \\
\qquad(Y A-Z . A . \text { E/73). }\end{array}$ & $\begin{array}{l}\text { Eskiden de kullanılan sözcük } \\
\text { "fikir" anlamında } \\
\text { canlandırılmıştır (Bayar, } \\
\text { 2006:148). }\end{array}$ \\
\hline gündem & "Ruznâme" & "onları da gündeme alır” (LA - R.Ç. E/64). & \\
\hline güney & “Cenup" & "güneylık bi yer olur" (AADKA - S.K. E/58). & $\begin{array}{l}\text { Eskiden de kullanılan sözcük } \\
\text { "cenup" anlamında } \\
\text { canlandırılmıştır (Bayar, } \\
\text { 2006:147). }\end{array}$ \\
\hline güven- & "İtimat etmek" & $\begin{array}{c}\text { “inanamiyusun ki rüye kime güveneceksin" (AADKA- } \\
\text { F.T. K/68) (2) } \\
\text { "sen çok güveniyosun ki benum bahçemde koparíyosun" } \\
\text { (AADKA-H.A. K/60) } \\
\text { "dedum bana güvenme" (AADKA-S.K. E/58) } \\
\text { "atına güvenisen sen de yarışa atın koyeriyosun" (YYA- } \\
\text { M.P. E/80) (2). }\end{array}$ & $\begin{array}{l}\text { Eskiden de kullanılan sözcük } \\
\text { "itimat etmek" anlamında } \\
\text { canlandırılmıştır (Bayar, } \\
\text { 2006:148). }\end{array}$ \\
\hline 1ş1- & $\begin{array}{l}\text { “Tenevvür } \\
\text { etmek, 1şık } \\
\text { saçmak” }\end{array}$ & 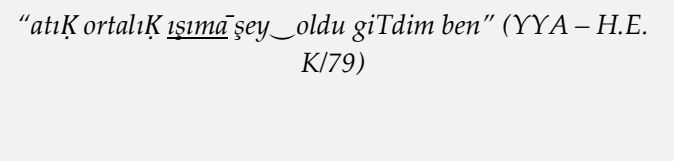 & $\begin{array}{c}\text { Eskiden de kullanılan sözcük } \\
\text { "tenevvür etmek" anlamında } \\
\text { canlandırılmıştır (Bayar, } \\
\text { 2006:154). }\end{array}$ \\
\hline ileri gelen & “Eşraf" & $\begin{array}{c}\text { "ileri gelennere yemek_ısmarlamış yemeK getirin demiş" } \\
\text { (YYA-R.T. E/80) }\end{array}$ & \\
\hline ilgilen- & $\begin{array}{l}\text { "Alâkadar } \\
\text { olmak" }\end{array}$ & $\begin{array}{l}\text { "boyle ilgileniyuruz işte" ( AADKA - K.K. E/79) } \\
\text { "bélki de ilgilendirebilir" (LA - R.Ç. E/64) (2) } \\
\text { şindi herkes_ilgileniyo gelinnen (YYA-E.E. K/73) (3) } \\
\text { "kadınsa kadinläilgileniyodu" (YYA-H.T. K/79). }\end{array}$ & $\begin{array}{l}\text { Eskiden de kullanılan sözcük } \\
\text { "alâkadar olmak"” anlamında } \\
\text { canlandırılmıştır (Bayar, } \\
\text { 2006:160). }\end{array}$ \\
\hline ilgili & $\begin{array}{l}\text { "Alâkalı, } \\
\text { alâkadar, } \\
\text { müteallık" }\end{array}$ & "tarmmla ilgili mı senin de"(LA - S.G. E/61). & \\
\hline ilginç & $\begin{array}{l}\text { "Enteresan, } \\
\text { alâkabahş" }\end{array}$ & “böle fazla ilginș şeler yoḲ” (YYA - O.G. E/67) (4). & $\begin{array}{l}\text { Bu kullanımlardan üçü } \\
\text { derlemecinin sorduğu "ilginç" } \\
\text { sözcügüünü içeren soruya } \\
\text { cevaben söylenmiştir ve } \\
\text { soruda kullanılan sözcügüun } \\
\text { tekrarı niteliğindedir. }\end{array}$ \\
\hline ilkin & "İptidâ, başta" & “ilkin bi söyüş dèrdiK” (YYA - H.T. K/79) (2). & $\begin{array}{l}\text { Eskiden de kullanılan sözcük } \\
\text { KT'de yer almaktadır (Bayar, } \\
\text { 2006:163). }\end{array}$ \\
\hline
\end{tabular}


Türkiye Türkçesinde 1930’lu Yıllardan Sonra Türetilen veya Canlandırılan Yeni Sözcüklerin Ağız Metinlerine Etkisinin Bir Örneklem Üzerinden Değerlendirilmesi

\begin{tabular}{|c|c|c|c|}
\hline ilkel & $\begin{array}{l}\text { "İbtidâi, } \\
\text { eğitimsiz" }\end{array}$ & "burda işTe ilkel aletlerlen" (YYA - N.Ö. E/56) (2). & \\
\hline inanç & $\begin{array}{l}\text { "İman, itikat, } \\
\text { öneri" }\end{array}$ & “böyle işde batıl_inanç ama” (YYA - F.P. K/67). & $\begin{array}{l}\text { Eskiden de kullanılan sözcük } \\
\text { "iman, itikat"”' anlamında } \\
\text { canlandırılmıştır (Bayar, } \\
\text { 2006:165). }\end{array}$ \\
\hline işlem & "Muamele" & "fabrika da isleme geçmesi lazím" (AADKA - Z.T. E/72). & \\
\hline izle- & $\begin{array}{l}\text { "Takip etmek, } \\
\text { seyretmek" }\end{array}$ & $\begin{array}{l}\text { "bahmiş, izlamiş biǩaç dafa" (YA - Y.T. E/79) } \\
\text { "işde oyle dizi izleduğum dizi işde" (AADKA - H.G. } \\
\text { K/82). }\end{array}$ & $\begin{array}{l}\text { Not1: Eskiden de kullanılan } \\
\text { sözcük “seyretmek"” } \\
\text { anlamında canlandırılmıştır } \\
\text { (Bayar, 2006:168). } \\
\text { Not2: AADKA kaynak } \\
\text { kişilerinden H.G.'nin } \\
\text { kullandığ1 örnek derlemecinin } \\
\text { sorduğu “Televizyon izlemeyi } \\
\text { seviyor musun?" sorusuna } \\
\text { cevaben söylenmiştir ve } \\
\text { soruda kullanılan sözcüğün } \\
\text { tekrarı niteliğindedir. }\end{array}$ \\
\hline kasım & “Teşrinisâni” & $\begin{array}{l}\text { "kasım aylaríydí böyle" (AADKA - S.G. K/45) } \\
\text { "ekim, kasım ayindá" (AADKA-S.K. E/58) (2) }\end{array}$ & $\begin{array}{l}\text { Arapça “kāsım” sözcüğünden } \\
\text { gelmektedir ve KT'de de yer } \\
\text { alır (Bayar, 2006:175). }\end{array}$ \\
\hline kazı & "Hafriyat" & $\begin{array}{c}\text { "hamamın mesel̄a yerini çıkarıyo meydana ġazıda" (YYA- } \\
\text { A.G. E/93). }\end{array}$ & \\
\hline kesin & “Kat'i” & $\begin{array}{l}\text { "kesin olurdu" (AADKA-E.B. K/49) } \\
\text { “kesinn döniş mi yaptın" (AADKA-S.B. K/82) (2) } \\
\text { "para da demiştur kesin" }(Y A-H . Y . \text { K/67) } \\
\text { "belli mi kesin" (YA - Y.Ö. E/80). }\end{array}$ & \\
\hline kimlik & $\begin{array}{l}\text { "Hüviyet, } \\
\text { kimlik belgesi" }\end{array}$ & "sizin kimliK nerde" (YYA-N.Ö. E/56). & \\
\hline komutan & “Kumandan” & $\begin{array}{c}\text { "ben tabur komutanıym diyo" (AADKA - S.K. E/58) (3) } \\
\text { "Ǩolay mi dedim bu askerlik yani burada bu cahel } \\
\text { komutanlarla" }(Y A-R . D . \text { E/67). }\end{array}$ & $\begin{array}{l}\text { Askerlikle ilgili bir terim } \\
\text { olarak kullanılmıştır. }\end{array}$ \\
\hline konut & $\begin{array}{l}\text { "Mesken, } \\
\text { ikametgâh }\end{array}$ & “dedik ki bi konudumuz olsun” (YA-R.D. E/67). & \\
\hline
\end{tabular}


Türkiye Türkçesinde 1930’lu Yıllardan Sonra Türetilen veya Canlandırılan Yeni Sözcüklerin Ağız Metinlerine Etkisinin Bir Örneklem Üzerinden Değerlendirilmesi

\begin{tabular}{|c|c|c|c|}
\hline kutla- & "Tesit etmek" & 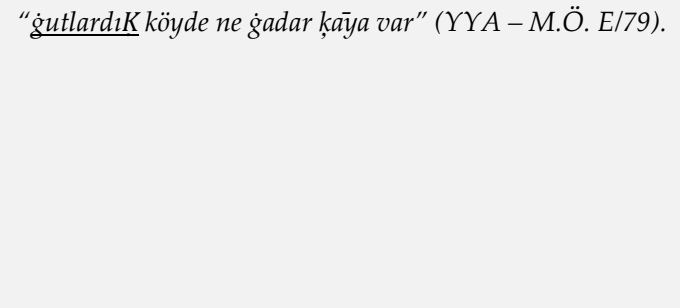 & $\begin{array}{l}\text { YYA kaynak kişilerinden } \\
\text { M.Ö.'nün kullandığı örnek } \\
\text { derlemecinin sorduğu } \\
\text { “Hıdrellez kutlar mıydınız } \\
\text { burada?" sorusuna cevaben } \\
\text { söylenmiştir ve soruda } \\
\text { kullanılan sözcüğün tekrarı } \\
\text { niteliğindedir. }\end{array}$ \\
\hline kuzey & “Şimal" & “kuzeyde olmaz" (AADKA - S.K. E/58). & $\begin{array}{l}\text { Eskiden de kullanılan sözcük } \\
\text { "şimal” anlamında } \\
\text { canlandırılmıştır (Bayar, } \\
\text { 2006:191). }\end{array}$ \\
\hline mutlu & "Mesut" & $\begin{array}{l}\text { "țatli yaşiyasin mutli yaşiyasın" (YA- F.K. K/94) } \\
\text { "mutlu olunurdu yani" (AADKA - S.G. K/45). }\end{array}$ & $\begin{array}{l}\text { Eskiden de kullanılan bir } \\
\text { sözcüktür. }\end{array}$ \\
\hline mutluluk & "Saadet" & "hala daha mutluluk beşundeyiz" (AADKA - H.E. K/89). & \\
\hline okul & “Mektep" & 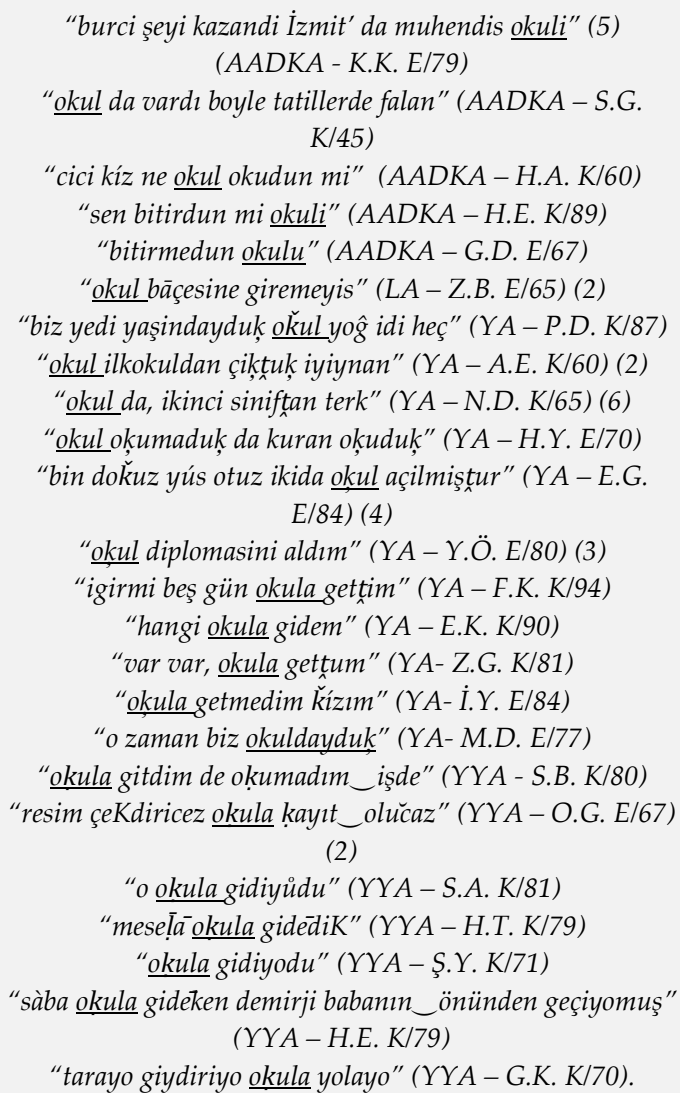 & $\begin{array}{l}\text { Bu kullanımlardan beş tanesi } \\
\text { LA, YA ve YYA isimli } \\
\text { çalışmalarda derleyicilerin söz } \\
\text { konusu kelimeyi kullanarak } \\
\text { sorduğu sorulara cevaben } \\
\text { kaynak kişiler } \\
\text { Z.B., N.D., E.K., S.B., O.G. } \\
\text { tarafından bu sorulara cevaben } \\
\text { ve sorularda kullanılan } \\
\text { sözcüklerin tekrarı niteliğinde } \\
\text { söylenmiştir. }\end{array}$ \\
\hline
\end{tabular}


Türkiye Türkçesinde 1930’lu Yıllardan Sonra Türetilen veya Canlandırılan Yeni Sözcüklerin Ağız Metinlerine Etkisinin Bir Örneklem Üzerinden Değerlendirilmesi

\begin{tabular}{|c|c|c|c|}
\hline olay & "Hâdise" & $\begin{array}{c}\text { "bu arada makas olayi çıtı" (AADKA - A.G. E/54) (4) } \\
\text { "ağıt olaylari yaşlilar genelde yaşlilar ağıt } \\
\text { yakarlar"(AADKA - A.B. K/43). }\end{array}$ & $\begin{array}{l}\text { AADKA kaynak kişilerinden } \\
\text { A.B.'nin kullandığı örnek } \\
\text { derlemecinin sorduğu "Ağıt } \\
\text { olayları nasıldır?" sorusuna } \\
\text { cevaben söylenmiştir ve } \\
\text { soruda kullanılan sözcüğün } \\
\text { tekrarı niteliğindedir. }\end{array}$ \\
\hline onarım & "Tâmirat, tâmir" & "onarımını hükúmetimiz yapíyor" (AADKA - Z.T. E/72). & \\
\hline ortam & $\begin{array}{l}\text { "İçinde } \\
\text { bulunulan çevre, } \\
\text { şartlar, durum" }\end{array}$ & $\begin{array}{l}\text { "oyleydi ortam oyleydi" (AADKA - K.K. E/79) } \\
\text { "şindi o ortam yok" (LA - S.G. E/61). }\end{array}$ & \\
\hline öğretmen & $\begin{array}{l}\text { "Muallim, } \\
\text { muallime" }\end{array}$ & 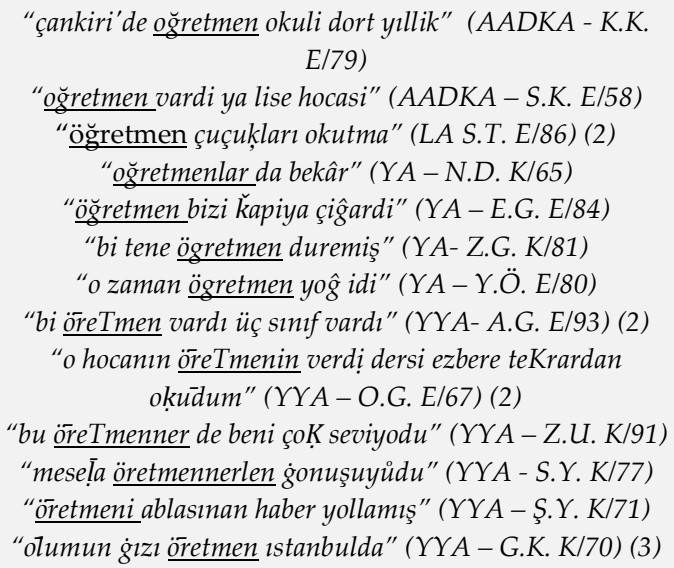 & $\begin{array}{l}\text { LA kaynak kişilerinden } \\
\text { S.T.'nin kullandığı örneklerden } \\
\text { biri derlemecinin kullandığı " } \\
\text { Öğretmen çıkacağım.” } \\
\text { cümlesinin ardından } \\
\text { söylenmiştir ve bahsi geçen } \\
\text { cümlede kullanılan sözcüğün } \\
\text { tekrarı niteliğindedir. }\end{array}$ \\
\hline ölçü & “Vezin” & $\begin{array}{l}\text { "ona göre ölçüyle korum" (LA-M.T. K/88) (2) } \\
\text { "kimisi ölçüylen yaPıyo" (YYA-F.K. K/77) } \\
\text { "ekiyorus tarlaya böle ölçülen" (YYA-A.L. E/85) } \\
\text { "at semer_örçüsüu verdi mi" (YYA- O.G. E/67). }\end{array}$ & $\begin{array}{l}\text { “Eskiden de kullanılan sözcük } \\
\text { “vezin” karşılığında } \\
\text { canlandırılmıştır (Bayar, } \\
\text { 2006:217). }\end{array}$ \\
\hline önemli & $\begin{array}{l}\text { "Mühim, } \\
\text { ehemmiyetli" }\end{array}$ & $\begin{array}{c}\text { "evet şans çok onemli" (AADKA-H.A. K/60) } \\
\text { "en önemli özelliği geleneksel tohum yönteminle tarrm } \\
\text { yapryo" (LA - G.K. E/49) } \\
\text { "önemni insannarı da at_arabalarıly yahut öküz } \\
\text { arabalarnyla getirịler" (YYA-M.Ö. E/79). }\end{array}$ & \\
\hline önemse- & "Mühimsemek" & “heralda önemsemedim” (AADKA-S.G. K/45). & \\
\hline örnek & $\begin{array}{c}\text { "Misal, } \\
\text { numune" }\end{array}$ & $\begin{array}{l}\text { "ben örnek diyim bu kışın yapdım" (AADKA - S.G. K/45) } \\
\text { "mısır sırası örgü örneyi de yaS böyle" (YYA - F.P. K/67) }\end{array}$ & $\begin{array}{l}\text { “Kaynağı hakkında muhtelif } \\
\text { görüşler mevcuttur. Fakat } \\
\text { Türkçede daha önce de } \\
\text { kullanılmaktaydı (Bayar, } \\
\text { 2006:224). }\end{array}$ \\
\hline örneğin & "Meselâ" & “örneğin poturcu diyuz" (AADKA - A.G. E/54) & \\
\hline
\end{tabular}


Türkiye Türkçesinde 1930’lu Yıllardan Sonra Türetilen veya Canlandırılan Yeni Sözcüklerin Ağız Metinlerine Etkisinin Bir Örneklem Üzerinden Değerlendirilmesi

\begin{tabular}{|c|c|c|c|}
\hline özel & "Husûsi" & 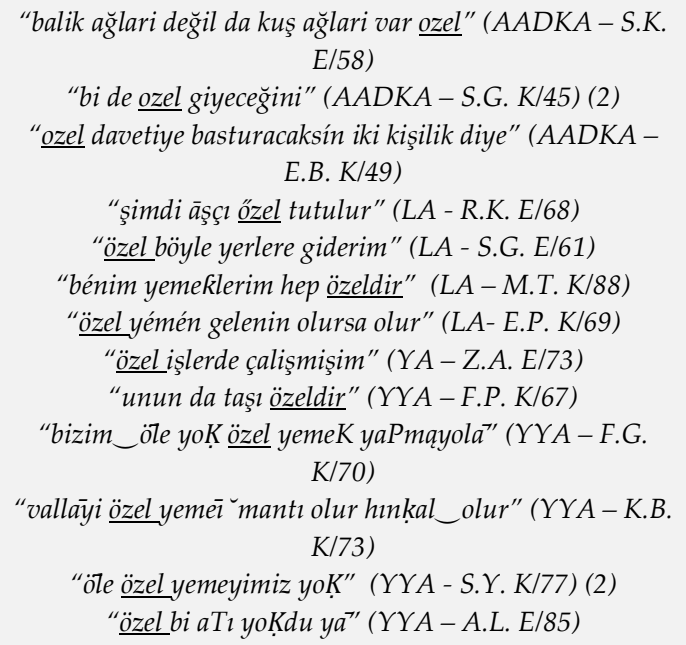 & $\begin{array}{l}\text { LA kaynak kişilerinden M.T. } \\
\text { ve E.P ile YYA kaynak } \\
\text { kişilerinden F.G., K.B. ve } \\
\text { S.Y'nin kullanımları } \\
\text { derleyicilerin söz konusu } \\
\text { kelimeyi kullanarak sordukları } \\
\text { sorulara cevaben söylenmiştir } \\
\text { ve sorularda kullanılan } \\
\text { sözcüklerin tekrarı } \\
\text { niteliğindedir. }\end{array}$ \\
\hline özellik & "Hususiyet" & $\begin{array}{c}\text { "laz börenin özelliği muhallebisindedir"(AADKA-A.B. } \\
\text { K/43) } \\
\text { "en önemli özelliği geleneksel tohum yönteminle, tarım } \\
\text { yapryo" (YYA- G.K. K/70). }\end{array}$ & \\
\hline özen- & $\begin{array}{l}\text { "İtinâ etmek, } \\
\text { birini taklit } \\
\text { hevesine } \\
\text { düşmek." }\end{array}$ & "yani ozenildi" (AADKA - Z.T. E/72). & $\begin{array}{l}\text { “Eskiden de kullanılan sözcük } \\
\text { “ itinâ etmek" karşılığında } \\
\text { canlandırılmıştır (Bayar, } \\
\text { 2006:230). }\end{array}$ \\
\hline özgü & "Has, mahsus" & "bizım şeyde yetişiyo, bize ozgü" (AADKA - A.B. K/43). & \\
\hline özgür & $\begin{array}{l}\text { "Hür serbest, } \\
\text { bağımsız" }\end{array}$ & “özgür mözgür böte bi şelēyaPmayoz” (YYA - F.G. K/70). & $\begin{array}{l}\text { YYA kaynak kişilerinden } \\
\text { F.G.'nin kullanımı derleyicinin } \\
\text { sorduğu “Bu köye özgü bir } \\
\text { geleneğiniz var mı aklınıza } \\
\text { gelen?” sorusundaki kelimenin } \\
\text { yanlış anlaşılmasına binaen } \\
\text { söylenmiştir ve soruda } \\
\text { kullanılan sözcügün tekrarı } \\
\text { niteliğindedir. }\end{array}$ \\
\hline savcı & $\begin{array}{l}\text { “Müddeiumûmi } \\
\text { ” }\end{array}$ & "adliyede duruyo savci yaninda"(YYA - G.K. K/70). & $\begin{array}{l}\text { Halk ağzından alınarak } \\
\text { canlandırılmıştır. }\end{array}$ \\
\hline saygıdeğer & "Muhterem" & $\begin{array}{c}\text { "saygıdeğer kişilar iş̧ta yani sözü geçan kişilari çâ̆ururdi" } \\
(Y A-A . B . \text { E/67) }\end{array}$ & \\
\hline sığın- & $\begin{array}{l}\text { "İlticâ etmek, } \\
\text { güvenmek, } \\
\text { yardım istemek" }\end{array}$ & "kız_oraya sīnmıs" (YYA-F.P. K/67). & $\begin{array}{l}\text { “Eskiden de kullanılan sözcük } \\
\text { canlandırılmıştır" (Bayar, } \\
\text { 2006:252). }\end{array}$ \\
\hline
\end{tabular}


Türkiye Türkçesinde 1930’lu Yıllardan Sonra Türetilen veya Canlandırılan Yeni Sözcüklerin Ağız Metinlerine Etkisinin Bir Örneklem Üzerinden Değerlendirilmesi

\begin{tabular}{|c|c|c|c|}
\hline sinir & "Hudut" & "vih deruk erzúrum artvin il sınırı hayvan sırtında" & $\begin{array}{l}\text { “Aslı Yunancadır. Eskiden de } \\
\text { kullanılmaktaydı. Tekrar } \\
\text { canlandırılmıştır." }\end{array}$ \\
\hline sonuç & $\begin{array}{l}\text { "Netice, nihayet, } \\
\text { en son, âkıbet, } \\
\text { en sonra, } \\
\text { sonunda" }\end{array}$ & $\begin{array}{c}\text { "istadum vermadi sonuc orya vardi" (YA-A.B. E/67) (2) } \\
\text { "misket miskeTdir gene miskeTdir sonușda yañi" (YYA- } \\
\text { N.Ö. E/56). }\end{array}$ & \\
\hline sorun & $\begin{array}{l}\text { "Mesele, } \\
\text { problem" }\end{array}$ & "su çıktı mı şey yok, sorun yok" (LA- E.P. K/69). & \\
\hline soyadı & $\begin{array}{l}\text { "Herkesin öz } \\
\text { adından başka } \\
\text { anıldığı aile adı" }\end{array}$ & $\begin{array}{l}\text { "merhaba adİm recep soyadÌm kírimli" (YA-R.K. E/94) } \\
\text { "adum firdes soyadım da albayrak" (YA- F.A. K/73) } \\
\text { "adum elif soyadum da kara" (YA-E.K. K/90) } \\
\text { "slyadını bilmeyom ama lütfiye bunun_adı" (YYA-H.D. } \\
\text { K/84). }\end{array}$ & $\begin{array}{l}\text { YA kaynak kişilerinden R.K., } \\
\text { F.A. ve E.K.'nin kullanımları } \\
\text { derleyicinin sorduğu soruda } \\
\text { geçen kelimenin tekrarı } \\
\text { niteliğindedir. }\end{array}$ \\
\hline sözde & "Sanki, güya" & $\begin{array}{l}\text { "çaktirmuyurum ona sözde" (AADKA - S.K. E/58) } \\
\text { "gelinin yanına gidiyular gelin_onnara sözde artıK yalan } \\
\text { mı saȳi mi onu allah bilir bilemem" (YYA-S.A. K/81). }\end{array}$ & \\
\hline subay & "Zâbit" & 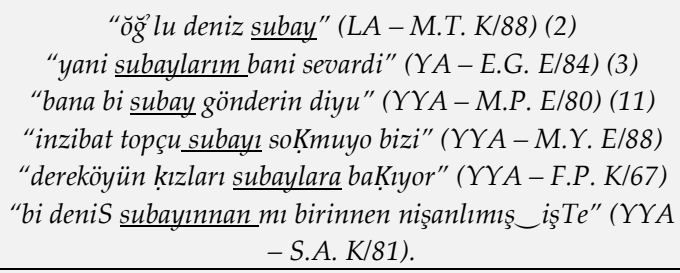 & $\begin{array}{l}\text { Not1: Askerlikle ilgili bir terim } \\
\text { olarak kullanılmıştır. } \\
\text { Not2: YYA kaynak kişilerinden } \\
\text { F.P.'nin kullanımı bir maninin } \\
\text { parçasıdır. }\end{array}$ \\
\hline süre & "Müddet" & $\begin{array}{c}\text { "bütün fu arları gezerim aşā yukart imkanım oldū sürede" } \\
\text { (LA - S.G. E/61). }\end{array}$ & \\
\hline süreç & "Vetîre" & "on üĉ lira bozuk para olarak o süreĉte" (YA-Z.A. E/73). & \\
\hline sürekli & $\begin{array}{l}\text { "Dâimi, } \\
\text { devamlı" }\end{array}$ & $\begin{array}{c}\text { “sürekli yanındá olan anlayamazmış" (AADKA - G.D. } \\
\text { E/67). }\end{array}$ & $\begin{array}{l}\text { Eskiden de kullanılan sözcük “ } \\
\text { dâimi, devamlı” karşlığında } \\
\text { canlandırılmıştır (Bayar, } \\
\text { 2006:264). }\end{array}$ \\
\hline tarim & "Ziraat" & $\begin{array}{l}\text { "o tarım baǩanlìğíndan" (LA - R.K. E/68) } \\
\text { "gerçekten burada tarím olarak zirai çay üreticisiyiz" } \\
\text { (AADKA - Z.T. E/72). }\end{array}$ & $\begin{array}{l}\text { LA Kaynak kişilerinden } \\
\text { R.K.'nin kullanımı bir devlet } \\
\text { kuruluşu isminde } \\
\text { geçmektedir. }\end{array}$ \\
\hline
\end{tabular}


Türkiye Türkçesinde 1930’lu Yıllardan Sonra Türetilen veya Canlandırılan Yeni Sözcüklerin Ağız Metinlerine Etkisinin Bir Örneklem Üzerinden Değerlendirilmesi

\begin{tabular}{|c|c|c|c|}
\hline temel & $\begin{array}{l}\text { “Esas, bir şeyin } \\
\text { yerleşmesi için } \\
\text { gerekli ilk ve } \\
\text { mühim } \\
\text { unsurlar" }\end{array}$ & 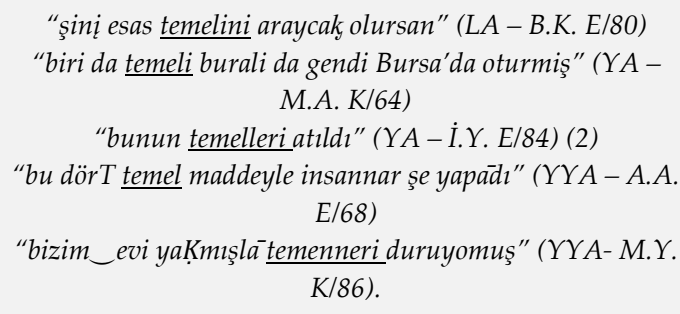 & $\begin{array}{c}\text { Eskiden de kullanılan Yunanca } \\
\text { kökenli sözcük yeniden } \\
\text { canlandırılmıştır (Bayar, } \\
\text { 2006:275). }\end{array}$ \\
\hline tepki & $\begin{array}{l}\text { “Aksülamel, } \\
\text { reaksiyon” }\end{array}$ & $\begin{array}{c}\text { "hani tepki bekliyorum bi şey söylesin diye de" (AADKA- } \\
\text { G.D. E/67) } \\
\text { "bi şeye öle bi tepki veriyorus" (YYA-O.G. E/67). }\end{array}$ & \\
\hline toplant1 & "İçtima" & $\begin{array}{l}\text { "şeye gittuk rize'de toplanti oldi" (AADKA - K.K. E/79) } \\
\text { "yine burda bi toplantıda anlattım" (YA - I.G. E/73) } \\
\text { "bilmiyom öle toplantı moplantı oluyo mudu" (YYA- } \\
\text { M.B. E/76). }\end{array}$ & \\
\hline toplum & $\begin{array}{l}\text { "Cemiyet, } \\
\text { topluluk" }\end{array}$ & "toplum deỷişđi" (LA - S.G. E/61). & \\
\hline töre & $\begin{array}{l}\text { "Âdetler ve } \\
\text { görenekler" }\end{array}$ & “bizim èvelki töremiS tāịydi” (YYA - G.K. K/70). & $\begin{array}{l}\text { “Eskiden de kullanılan sözcük } \\
\text { canlandırılmıştır" (Bayar, } \\
\text { 2006:279). }\end{array}$ \\
\hline tören & "Merâsim" & "takı törenimiz $u \bar{y} d u$ " (YYA - G.K. K/70) (2). & $\begin{array}{l}\text { YYA kaynak kişilerinden } \\
\text { G.K.'nin kullanımı derleyicinin } \\
\text { sorduğu “Takı törenini de anlatır } \\
\text { mısınız?” sorusuna cevaben } \\
\text { söylenmiştir ve soruda } \\
\text { kullanılan sözcügüün tekrarı } \\
\text { niteliğindedir. }\end{array}$ \\
\hline tüketim & "İstihlâk" & "millet yani tüketim yapsìn" (AADKA - K.K. E/79). & \\
\hline tür & “Çeşit, bölüm.” & "o tur sandık eşyası ille de alınırdı" (AADKA - S.G. K/45). & $\begin{array}{l}\text { “Eski Türkçede de } \\
\text { kullanılmaktaydı (Bayar, } \\
\text { 2006:285). }\end{array}$ \\
\hline
\end{tabular}


Türkiye Türkçesinde 1930'lu Yıllardan Sonra Türetilen veya Canlandırılan Yeni Sözcüklerin Ağız Metinlerine Etkisinin Bir Örneklem Üzerinden Değerlendirilmesi

\begin{tabular}{|c|c|c|c|}
\hline türlü & $\begin{array}{l}\text { “Muhtelif, nevi, } \\
\text { mütenevvi, } \\
\text { müteferrik, } \\
\text { kâbil" }\end{array}$ & 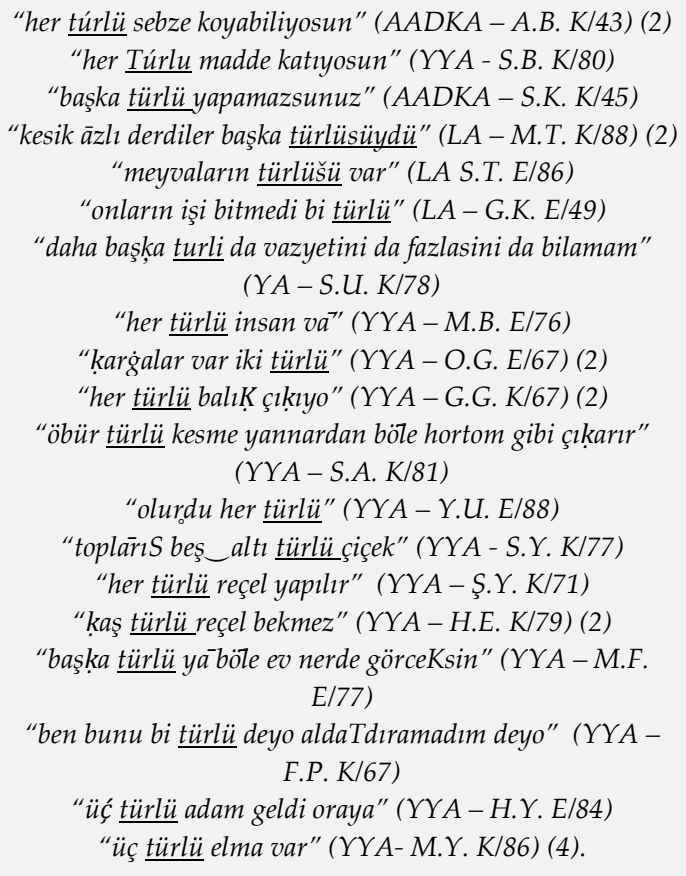 & \\
\hline uçak & "Tayyare" & $\begin{array}{c}\text { "uçak kazasında oldu ya o" (LA S.T. E/86) (3) } \\
\text { “uçak mı yollaycak" (LA-M.T. K/88) } \\
\text { "orda uçaktan enduk" (YA-S.I. E/85). }\end{array}$ & \\
\hline uçak savar & $\begin{array}{c}\text { "Hava } \\
\text { hedeflerine karşı } \\
\text { kullanılan } \\
\text { silahlara verilen } \\
\text { genel ad." } \\
\end{array}$ & "taĝ̀ıtım oldi úçak savar bölügündayduķ" (YA- A.T. E/78). & $\begin{array}{l}\text { Askerlikle ilgili olarak } \\
\text { kullanılmıştır. }\end{array}$ \\
\hline uygulan- & $\begin{array}{l}\text { "Tatbik } \\
\text { edilmek" }\end{array}$ & $\begin{array}{c}\text { "aslındá boğaz yapsák uygulanurdio tepede" (AADKA- } \\
\text { S.K. E/58) (2). }\end{array}$ & \\
\hline uzman & "Mütehassis" & "babam onun uzmaniydi" (AADKA - A.G. E/54). & \\
\hline üretici & "Müstahsil" & "zirai çay ureticisiyiz" (AADKA - Z.T. E/72) (2) & \\
\hline üretim & "İstihsal" & 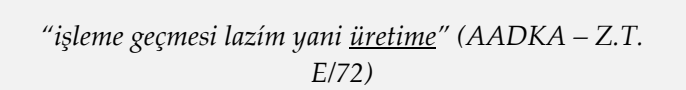 & \\
\hline
\end{tabular}


Türkiye Türkçesinde 1930’lu Yıllardan Sonra Türetilen veya Canlandırılan Yeni Sözcüklerin Ağız Metinlerine Etkisinin Bir Örneklem Üzerinden Değerlendirilmesi

\begin{tabular}{|c|c|c|c|}
\hline ürün & “Mahsul, eser" & $\begin{array}{c}\text { “korumak haşerelerden üründen" } \\
\text { "2) } \\
\text { "elde edilen úrún da hiç bi işe yaramaz" (AADKA - A.T. E/54) } \\
\text { E/72) } \\
\text { "en değerli bir úrúndúr" (AADKA - S.B. E/54) } \\
\text { "tatmer gözleme süt ürünlerine" (LA S.T. E/86). }\end{array}$ & $\begin{array}{l}\text { Not1: Eski Anadolu Türkçesi } \\
\text { ve halk ağzında yaşayan } \\
\text { sözcükten anlam } \\
\text { genişlemesiyle türetilmiştir } \\
\text { (Bayar, 2006:301). } \\
\text { Not2: AADKA kaynak } \\
\text { kişilerinden A.G.'nin } \\
\text { kullanımları derleyicinin } \\
\text { sorduğu sorulara cevaben } \\
\text { söylenmiştir ve sorularda } \\
\text { kullanılan sözcüğün tekrarı } \\
\text { niteliğindedir }\end{array}$ \\
\hline verimli & "Mümbit, velut" & "toprak yăni verimli" (AADKA - Z.T. E/72). & $\begin{array}{l}\text { Halk ağzından alınarak } \\
\text { canlandırılmıştır (Bayar, } \\
\text { 2006:304). }\end{array}$ \\
\hline yapım & $\begin{array}{l}\text { "İnşa, îmal, } \\
\text { prodüksiyon" }\end{array}$ & $\begin{array}{l}\text { "Ersis'țe oralarda yol yapımına gidárduk" (AADKA-A.B. } \\
\text { K/43). }\end{array}$ & \\
\hline yaklaşık & "Takrîbi" & "yaklașík o kada var mí?" (AADKA - A.G. E/54) (9). & \\
\hline yarbay & $\begin{array}{l}\text { “Orduda } \\
\text { aşaması binbaşı } \\
\text { ile albay } \\
\text { arasında olan } \\
\text { üstsubay; } \\
\text { kaymakam." }\end{array}$ & "yarbay vardı alay kumandanı" (YYA - F.K. E/70). & $\begin{array}{l}\text { Askerlikle ilgili olarak } \\
\text { kullanılmıştır. }\end{array}$ \\
\hline yarış & $\begin{array}{l}\text { "Müsâbaka, } \\
\text { rekâbet" }\end{array}$ & 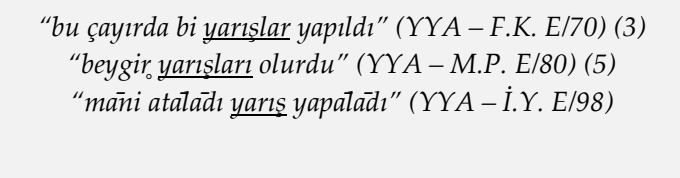 & $\begin{array}{l}\text { Eskiden de kullanılan sözcük } \\
\text { "müsâbaka" karşılığında } \\
\text { canlandırılmıştır (Bayar, } \\
\text { 2006:315). }\end{array}$ \\
\hline yaşam & "Ömür, hayat" & 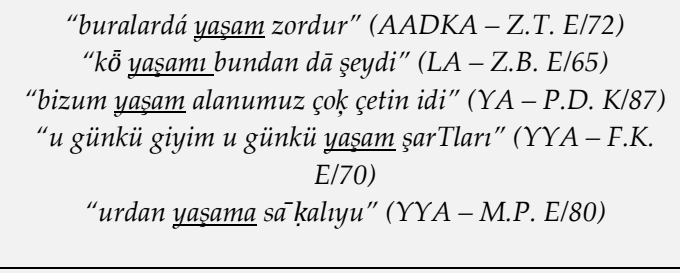 & $\begin{array}{l}\text { AADKA kaynak kişilerinden } \\
\text { Z.T. ve LA kaynak kişilerinden } \\
\text { Z.B.'nin kullanımları } \\
\text { derleyicinin sorduğu sorulara } \\
\text { cevaben söylenmiştir ve } \\
\text { sorularda kullanılan sözcüğün } \\
\text { tekrarı niteliğindedir } \\
\end{array}$ \\
\hline yaşantı & $\begin{array}{l}\text { "Hayat } \\
\text { tecrübesi, } \\
\text { hayatın bir } \\
\text { bölümü, hayat" }\end{array}$ & $\begin{array}{l}\text { "yaşantı yokdu" (LA S.T. E/86) } \\
\text { "eski yașantilerden unutulmiş yani vardur" (YA-Z.A. } \\
\text { E/73) (2) } \\
\text { "yani zor yașantidayiz" (YA - R.D. E/67). }\end{array}$ & \\
\hline
\end{tabular}


Türkiye Türkçesinde 1930’lu Yıllardan Sonra Türetilen veya Canlandırılan Yeni Sözcüklerin Ağız Metinlerine Etkisinin Bir Örneklem Üzerinden Değerlendirilmesi

\begin{tabular}{|c|c|c|c|}
\hline yatırım & $\begin{array}{l}\text { "Mevduat, } \\
\text { envestisman" }\end{array}$ & “yatırımı varısa ĕger ǩkııni veriyo" (YA - R.D. E/67). & \\
\hline yaygın & $\begin{array}{l}\text { “Münteşir, } \\
\text { birçoklarınca } \\
\text { duyulmuş ya da } \\
\text { kullanılmış" }\end{array}$ & $\begin{array}{l}\text { "el işi yaygındı tabi bizim zamanımızde" (AADKA - S.G. } \\
\text { K/45) (4). }\end{array}$ & \\
\hline yeterli & $\begin{array}{l}\text { "Kifayetli, } \\
\text { ehliyetli, ehil" }\end{array}$ & $\begin{array}{l}\text { "bu kadar yeterli mi" (LA - G.K. E/49) } \\
\text { “o da yeterli cevap veremiyu" (AADKA - A.G. E/54). }\end{array}$ & \\
\hline yetkili & $\begin{array}{l}\text { "salâhiyettar, } \\
\text { mezun" }\end{array}$ & $\begin{array}{c}\text { "sesimizi da yetkililara duyuramıyoruz" (YA-R.D. E/67) } \\
\text { (3) } \\
\text { "köyde biz yetkiliydiK ablamlan_ikimiz" (YYA-F.P. } \\
\text { K/67). }\end{array}$ & \\
\hline yitir- & “Kaybetmek" & "alla yitirmediKden soña annayışlıydı" (YYA - S.Y. K/77). & $\begin{array}{l}\text { Eskiden de kullanılan sözcük } \\
\text { canlandırılmıştır (Bayar, } \\
\text { 2006:327). }\end{array}$ \\
\hline yoğunluk & "Kesâfet" & $\begin{array}{l}\text { "fazla yoğunluk olmadı̆̆ı içın tabi burda çay fazla tabi" } \\
\text { (AADKA - S.B. E/54) (2). }\end{array}$ & $\begin{array}{l}\text { Eskiden de kullanılan sözcük } \\
\text { canlandırılmıştır (Bayar, } \\
\text { 2006:328). }\end{array}$ \\
\hline yorumla- & $\begin{array}{l}\text { “Tefsir etmek, } \\
\text { tabir etmek, icrâ } \\
\text { etmek" }\end{array}$ & "kötíye bi yorumlaníyo yani" (AADKA - A.B. K/43). & \\
\hline yönet- & $\begin{array}{l}\text { "İdâre etmek, } \\
\text { tedvir etmek" }\end{array}$ & $\begin{array}{l}\text { "tercümanı vasıtasiyle durduru takımı yönetirdi" } \\
(Y Y A-F . K . \text { E/70). }\end{array}$ & \\
\hline yönetici & "İdâreci" & “onun bi yöneticisi var" (YA - Z.A. E/73). & \\
\hline yöntem & $\begin{array}{l}\text { "Sistem, usul, } \\
\text { metot" }\end{array}$ & $\begin{array}{l}\text { “geleneksel tohum yönteminle tarm yapıyo" (LA-G.K. } \\
\text { E/49). }\end{array}$ & \\
\hline yöre & "Havâli, dolay" & "yāni yörelerin şeleri denişiyo" (YYA - N.Ö. E/56). & $\begin{array}{l}\text { Eskiden de kullanılan sözcük } \\
\text { "civar, muhit" anlamlarında } \\
\text { canlandırılmıştır (Bayar, } \\
\text { 2006:331). }\end{array}$ \\
\hline yöresel & "Mahalli" & $\begin{array}{l}\text { "yöresel olarak buranun sarmasım yapdım" (AADKA- } \\
\text { S.G. K/45) } \\
\text { "yöresel oyunumuz yoK" (YYA- G.G. K/67) }\end{array}$ & $\begin{array}{l}\text { YYA kaynak kişilerinden } \\
\text { G.G.'nin kullanımı derleyicinin } \\
\text { sorduğu “Yöresel bir oyununuz } \\
\text { var mı?" sorusuna cevaben } \\
\text { söylenmiştir ve soruda } \\
\text { kullanılan sözcüğün tekrarı } \\
\text { niteliğindedir. }\end{array}$ \\
\hline
\end{tabular}

